\title{
A Tunable Nanoplatform of Nanogold Functionalised with Angiogenin Peptides for Anti-Angiogenic Therapy of Brain Tumours
}

\author{
Irina Naletova ${ }^{1}$, Lorena Maria Cucci ${ }^{2}$, Floriana $D^{\prime}$ Angeli $^{3}$, Carmelina Daniela Anfuso ${ }^{3}$, \\ Antonio Magrì ${ }^{4}\left(\mathbb{D}\right.$, Diego La Mendola ${ }^{1,5, *}$, Gabriella Lupo ${ }^{3, *}$ and Cristina Satriano ${ }^{1,2, *}$ (]) \\ 1 Consorzio Interuniversitario di Ricerca in Chimica dei Metalli nei Sistemi Biologici (CIRCMSB), \\ Via Celso Ulpiani 27, I-70126 Bari, Italy; irina_naletova@yahoo.com \\ 2 Hybrid NanobioInterfaces Lab (NHIL), Department of Chemical Sciences, University of Catania, \\ Viale Andrea Doria 6, I-95125 Catania, Italy; lorena.cucci@unict.it \\ 3 Department of Biomedical and Biotechnological Sciences, University of Catania, Via Santa Sofia 89, \\ I-95123 Catania, Italy; fdangeli@unict.it (F.D.); daniela.anfuso@unict.it (C.D.A.) \\ 4 Institute of Crystallography Catania, National Council of Research (IC-CNR), Via Paolo Gaifami 18, \\ I-95126 Catania, Italy; leotony@unict.it \\ 5 Department of Pharmacy, University of Pisa, via Bonanno Pisano 6, I-56126 Pisa, Italy \\ * Correspondence: lamendola@farm.unipi.it (D.L.M.); gabriella.lupo@unict.it (G.L.); csatriano@unict.it (C.S.); \\ Tel.: +39-050-2219533 (D.L.M.); +39-095-4781158 (G.L.); +39-095-7385136 (C.S.)
}

Received: 9 August 2019; Accepted: 3 September 2019; Published: 6 September 2019

\begin{abstract}
Angiogenin (ANG), an endogenous protein that plays a key role in cell growth and survival, has been scrutinised here as promising nanomedicine tool for the modulation of pro-/anti-angiogenic processes in brain cancer therapy. Specifically, peptide fragments from the putative cell membrane binding domain (residues 60-68) of the protein were used in this study to obtain peptide-functionalised spherical gold nanoparticles (AuNPs) of about $10 \mathrm{~nm}$ and $30 \mathrm{~nm}$ in optical and hydrodynamic size, respectively. Different hybrid biointerfaces were fabricated by peptide physical adsorption (Ang $60-68$ ) or chemisorption (the cysteine analogous Ang ${ }_{60-68} \mathrm{Cys}$ ) at the metal nanoparticle surface, and cellular assays were performed in the comparison with ANG-functionalised AuNPs. Cellular treatments were performed both in basal and in copper-supplemented cell culture medium, to scrutinise the synergic effect of the metal, which is another known angiogenic factor. Two brain cell lines were investigated in parallel, namely tumour glioblastoma (A172) and neuron-like differentiated neuroblastoma (d-SH-SY5Y). Results on cell viability/proliferation, cytoskeleton actin, angiogenin translocation and vascular endothelial growth factor (VEGF) release pointed to the promising potentialities of the developed systems as anti-angiogenic tunable nanoplaftforms in cancer cells treatment.
\end{abstract}

Keywords: plasmonics; nanomedicine; theranostics; copper; VEGF; glioblastoma; differentiated neuroblastoma; peptidomimetics; real-time quantitative polymerase chain reaction (qPCR); actin

\section{Introduction}

In recent decades, protein-nanoparticle and peptide-nanoparticle conjugates have emerged as powerful nanomedicine tools, enabling biomedical applications in the prevention, diagnosis and treatment of disease [1,2]. Unfunctionalised, bare nanoparticles (NPs), are often able to match several of the desired functions required by theranostic platforms, including the peculiar optical, electrical, magnetic properties of nanometer-sized materials [3], the tunable geometries and the tailored size and surface chemistry [4] and the intrinsic biological properties, such as anti-angiogenic nanogold $[5,6]$ or antibacterial nanosilver $[7,8]$. Biological protein-based nanoparticles are advantageous 
in having biodegradability, bioavailability, and relatively low cost. Many protein nanoparticles, for instance naturally occurring protein cages such as ferritin, are easy to process and can be modified to achieve desired specifications such as size, morphology, and weight [9-11]. Natural product-based nanomedicine include, among the most common types of nanoparticles, polymeric micelles, solid lipid nanoparticles, liposomes, inorganic nanoparticles and dendrimers [3,12].

Each of these nanoparticles has its own advantages and disadvantages as drug delivery vehicle. Hybrid peptide- or protein-NP conjugates enable addressing many of the difficulties that arise as results of in vivo applications, replacing many materials that have a poor biocompatibility and have a negative impact on the environment. Specifically, both naturally derived and synthetic polypeptides may offer improved biocompatibility [13], targeted delivery [14] and prolonged lifetime before clearance, to ensure an efficient therapeutic action $[1,15]$.

Angiogenin (ANG) is a secreted ribonuclease (also known as RNase 5), identified in media from cancer cells, but also present in normal tissues, such as plasma and amniotic fluid, and secreted from vascular endothelial cells, aortic smooth muscle cells, fibroblasts [16]. Angiogenin induces neovascularization by triggering cell migration, invasion, proliferation, and formation of tubular structures [16-19].

Physiologically, ANG is overexpressed during inflammation, exhibiting wound healing properties as well as microbicide activity and conferring host immunity [20]. However, uncontrolled activity of angiogenin is implicated in pathological processes.

The protein was isolated for the first time from medium conditioned by a human adenocarcinoma cell line (HT-29) [21]. A high expression of angiogenin has been described in different types of cancers and to their malignant transformation [16], including gliomas that are brain tumours fast-growing, aggressive and with a poor prognosis [22].

ANG expression has been identified also in neurons and acts as a part of the secretome of endothelial progenitor cells (EPCs) [23,24]; the modulation of ANG and EPCs as repair-associated factors has been found in stroke patients and mouse models of rehabilitation after cerebral ischemia [25]. Mutations in the ANG gene have been characterized in amyotrophic lateral sclerosis (ALS) [26] and Parkinson's disease (PD) [27]. Moreover, endogenous angiogenin levels are dramatically reduced in an alpha-synuclein mouse model of PD and exogenous angiogenin protects against cell loss in neurotoxin-based cellular models of PD [27]. Genetic studies revealed that angiogenin treatment delays motor dysfunction and motor neuron loss, also prolonging the survival in superoxide dismutase 1 (SOD1) mouse model of ALS [18].

In motor neurons, ANG can be upregulated by hypoxia thought the stimulation of ribosomal ribonucleic acid (rRNA) transcription of endothelial cells [28]. Such a process is critical for the cellular proliferation induced by other angiogenic proteins, including vascular endothelial growth factor (VEGF) [29]. While the predominant role of VEGF in the formation of new blood vessels is unquestioned, several recent studies demonstrate that VEGF also has trophic effects on neurons and glia in the central- (CNS) and peripheral- (PNS) nervous system, promoting neurogenesis, neuronal patterning, neuroprotection and glial growth [30]. Therefore, VEGF modulates neuronal health and nerve repair; and exogenous angiogenin delivery can be considered a promising tool of anti-angiogenic therapy for treating gliomas, where malignancy is highly related to angiogenesis.

Copper is an essential metal that plays a key role in the CNS development and function, and its dyshomeostasis is involved in many neurodegenerative diseases as Alzheimer's disease (AD), PD and ALS [31,32]. Furthermore, copper is known to be a strong angiogenic factor, with metal serum levels raising in a wide variety of human cancers [33,34]. Noteworthy, copper increases the expression of ANG and regulates its intracellular localization [35]. Moreover, ANG binds copper ions and the metal interaction largely influences its interaction with endothelial cells as well as its angiogenic activity [36-38]. Taking into account the correlations between angiogenin protein and copper in physiological and pathological conditions of the brain, a promising pharmacological approach in brain 
tumours therapy is the use of ANG as molecular target, whose activity may be modulated by the presence of copper ions.

As an alternative to protein-based drugs, peptides mimicking functional domains of the whole protein are becoming more relevant as drug candidates, to address problems exhibited by the protein in in vivo applications such as the additional effect or functions or binding sites for other ligands, the immunological clearance before reaching their target site $[39,40]$.

Three domains of angiogenin have been demonstrated essential to the protein to explicate its biological activity, i.e.,: the catalytic site (involving His-13, Lys-40, and His-114 residues), the nuclear translocation sequence (encompassing residues 31-35, RRRGL); the putative cellular binding site (residues 60-68, KNGNPHREN) [41,42]. In previous works, peptide fragments encompassing such different domains of the protein have been synthesized and used as mimicking model of the whole protein $[6,43,44]$. In particular, hybrid nano-assemblies of gold nanoparticles (AuNPs) functionalized with different peptides encompassing the putative cellular binding site of the protein $\left(\mathrm{Ang}_{60-68}\right)$ have been demonstrated able to maintain their activity on cytoskeleton actin reorganization in a tumour cell line of human neuroblastoma [44].

Here, we report on the investigation of AuNPs functionalised with the peptide Ang $_{60-68}$ or its analogous having a cysteine residue in the C-terminus ( $\mathrm{Ang}_{60-68} \mathrm{Cys}$ ), in the comparison with the whole ANG protein. Such systems have been scrutinised as potential nanomedicine platforms towards a brain cancer of human glioblastoma (A172 cell line). To compare the response of tumour and non-tumour brain cells, differentiated neuroblastoma (d-SH-SY5Y line) have been included in the study as model neuron-like cells.

Effects on cell proliferation, cytoskeleton actin changes, angiogenin translocation and VEGF expression upon the cell treatments with peptides- or protein-functionalized nanoparticles, in the absence or presence of copper ions, shed new light in the link between different factors involved in angiogenesis processes of non-tumour and tumour model brain cell cultures. Indeed, since ANG plays a key role in cell growth and survival, and the role of VEGF in brain tumour angiogenesis has been demonstrated [45], new perspectives in the therapeutic approaches may rely on the tiny modulation of the pro-/anti-angiogenic processes [46] for brain cancer treatment.

\section{Results}

\subsection{Physicochemical Characterisation of Hybrid Peptides- and Protein-NP Conjugates}

\subsubsection{Optical (Plasmonic) Properties Changes of AuNP upon Interaction with Peptides/Protein}

Peptide-functionalised NPs were fabricated by two different approaches, namely a purely physical adsorption and a prevalent covalent grafting, with the peptide sequences Ang ${ }_{60-68}$ and $\mathrm{Ang}_{60-68} \mathrm{Cys}$, respectively. As positive control, samples of ANG-functionalised AuNPs were prepared by using the whole protein.

Figure 1 shows the Ultraviolet (UV)-visible spectra of gold nanoparticles, before and after the addition of $A_{n}{ }_{60-68 n}$, Ang ${ }_{60-68}$ Cys or ANG, respectively. The plasmon peak parameters, i.e., the wavelength at the maximum absorbance $\left(\lambda_{\max }=519 \mathrm{~nm}\right)$ and the full width at half maximum $(\mathrm{FWHM}=54 \mathrm{~nm})$ point to the formation of a gold colloidal solution of spherical nanoparticles with an optical diameter of $11 \mathrm{~nm}$ [47].

The addition of $3 \times 10^{-5} \mathrm{M}$ Ang $60-68$ (Figure 1a) or Ang ${ }_{60-68}$ Cys (Figure 1b) induced comparable red-shifts $\left(\Delta \lambda_{\max }=3 \mathrm{~nm}\right)$ and hyperchromic-shifts $(\triangle A b s \sim 0.07)$, according to previous findings [44]. No significant changes in the width of the plasmon peak were detected. The addition of the $1 \times 10^{-7}$ M ANG whole protein (Figure 1c), lead to a significantly larger red-shift in the plasmon peak $\left(\Delta \lambda_{\max }=4 \mathrm{~nm}\right)$ with respect to the bare nanoparticles than those found upon the addition of the peptides. Moreover, a hypochromic-shift $(\triangle A b s=-0.09)$ in comparison to the bare AuNPs and a broadening of the plasmon band $(\triangle F H W M=11 \mathrm{~nm})$ with the appearance of a shoulder at around 600 $\mathrm{nm}$, were found, likely due to a partial nanoparticle aggregation. 

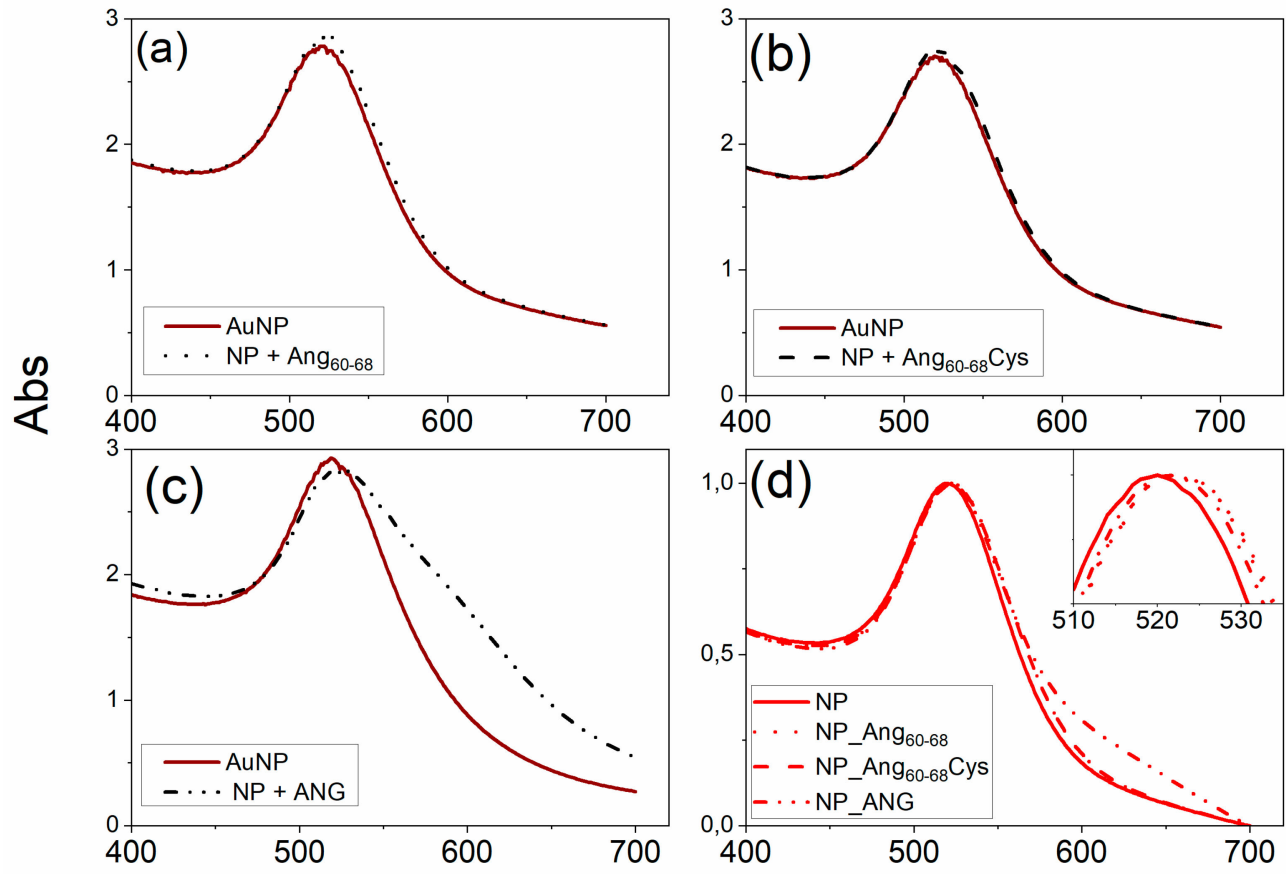

$\lambda(\mathrm{nm})$

Figure 1. (a-c) Ultraviolet (UV)-visible spectra of gold nanopartilces (AuNPs) in the $1 \mathrm{mM}$ 3-(N-morpholino)propanesulfonic acid)-Tris(2-carboxyethyl)phosphine hydrochloride (MOPS-TCEP) buffer (1:1 mol ratio) before and after the addition of: (a) $30 \mu \mathrm{M}$ Ang $_{60-68}$, (b) $30 \mu \mathrm{M}$ Ang $60-68$ Cys; (c) $100 \mathrm{nM}$ angiogenin (ANG). (d) UV-visible spectra of the pellets collected after two rinsing steps by centrifugation (15 min at 6010 relative centrifugal force, RCF) and re-suspension in $1 \mathrm{mM}$ MOPS-TCEP buffer.

As to the hybrid systems used for the cellular experiments, Figure $1 \mathrm{~d}$ shows the UV-visible spectra of the protein/peptide-nanoparticle pellets samples after two washing steps, performed to remove unbound and/or weakly bound biomolecules.

The red-shift in the plasmon peak with respect to the bare AuNPs is still visible $\left(\Delta \lambda_{\max } \sim 3 \mathrm{~nm}\right)$ for Ang $_{60-68}$ and Ang $_{60-68}$ Cys peptides as well as for ANG protein). This finding confirms the irreversible adsorption of the peptides and protein molecules and hence the successful surface functionalisation of the gold nanoparticles by the used biomolecules.

2.1.2. Hydrodynamic Size and Conformational Features of Peptides- and Protein-Functionalised NPs in the Absence or Presence of Copper Ions

To gain insight into the actual hydrodynamic size of the angiogenin-functionalised nanoparticles, dynamic light scattering was used to take into account the dynamic soft shell made by the peptide/protein molecules at the AuNP surface, in contrast to the optical size that reflects merely the 'dry state' or internal 'core' of the functionalised particle. The hydrodynamic size of $\sim 30 \mathrm{~nm}$ for the aqueous dispersion of gold nanoparticles $\left(1.7 \times 10^{8} \mathrm{NP} / \mathrm{mL}\right)$ did not change significantly upon addition of the peptide solution $\left(3 \times 10^{-5} \mathrm{M}\right)$, for both $\mathrm{Ang}_{60-68}$ and $\mathrm{Ang}_{60-68}$ Cys fragments (Table 1). On the other hand, by addition of ANG $\left(1 \times 10^{-7} \mathrm{M}\right)$, the nanoparticle size was largely increased in comparison to the bare AuNP, suggesting bridged interactions between the protein molecules immobilised at the nanoparticle surface that could also prompt a partial aggregation.

The Ang $60-68 \_N P$ and Ang ${ }_{60-68}$ Cys_NP pellets maintained a size range comparable to that of non-rinsed nanoparticles (both bare and functionalized), while a slight decrease in the size was found for ANG_NP, where a fraction of loosely bound proteins molecules was therefore likely rinsed off by the washing steps of the protein-nanoparticle hybrids. 
Table 1. Hydrodynamic size of the different NPs either before or after the functionalisation with the peptides or the protein, and after the addition of $20 \mu \mathrm{M} \mathrm{CuSO}_{4}$ aqueous solution.

\begin{tabular}{cccc}
\hline & \multicolumn{3}{c}{ Hydrodynamic Size (nm) } \\
\hline Peptide/Protein & $\begin{array}{c}\text { Nanoparticle (NP) + } \\
\text { Peptide/Protein (1) }\end{array}$ & Peptide/Protein_NP (2) & $\begin{array}{c}\text { Peptide/Protein_NP + } \\
\text { Cu(II) }{ }^{\text {(3) }}\end{array}$ \\
\hline- & $29 \pm 3$ & $30 \pm 2$ & $31 \pm 5$ \\
Ang $_{60-68}$ & $28 \pm 4$ & $37 \pm 4$ & $175 \pm 10$ \\
Ang $_{60-68}$ Cys & $30 \pm 3$ & $29 \pm 5$ & $281 \pm 42$ \\
ANG & $53 \pm 4$ & $41 \pm 6$ & $47 \pm 5$ \\
\hline
\end{tabular}

${ }^{1}$ peptide/protein-added NP samples; ${ }^{2}$ peptide/protein_NP samples after the centrifugation and rinsing steps;

${ }^{3}$ same pellets as 2 added with copper ions.

Noteworthy, after the addition of copper ions, the average dimension of nanoparticles was still unchanged for bare AuNP, instead a dramatic increase in the hydrodynamic diameter was found for Ang $_{60-68}{ }_{\text {NP }}$ (to $\sim 0.18 \mu \mathrm{m}$ ) and Ang $_{60-68}$ Cys_NP (to $\sim 0.3 \mu \mathrm{m}$ ), respectively.

The $\mathrm{Ang}_{60-68}$ peptide is able to bind copper at physiological $\mathrm{pH}$ by the involvement of one imidazole, two deprotonated amide nitrogen and one carboxyl oxygen atoms, respectively [48]. The UV-vis parameters measured for the equimolar solutions at $\mathrm{pH}=7.4$ of copper(II) and Ang ${ }_{60-68} \mathrm{Cys}$ $\left(\lambda_{\max }=624 \mathrm{~nm} ; \varepsilon=100 \mathrm{M}^{-1} \mathrm{~cm}^{-1}\right)$ were very similar to those of analogous complex formed with $\operatorname{Ang}_{60-68}\left(\lambda_{\text {max }}=630 \mathrm{~nm} ; \varepsilon=120 \mathrm{M}^{-1} \mathrm{~cm}^{-1}\right)$.

Accordingly, the circular dichroism (CD) spectra of both $\mathrm{Ang}_{60-68}+\mathrm{Cu}(\mathrm{II})$ and $\mathrm{Ang}_{60-68} \mathrm{Cys}+\mathrm{Cu}(\mathrm{II})$ (Figure 2) showed a minimum around $600 \mathrm{~nm}$, assigned to copper $\mathrm{d}-\mathrm{d}$ transition, and a broad band with a maximum approximately at $350 \mathrm{~nm}$, assigned to charge transfer to the metal ion by the imidazole nitrogen $\left(\mathrm{N}_{\mathrm{im}} \rightarrow \mathrm{Cu}(\mathrm{II})\right)$ and the deprotonated amide nitrogen $\left(\mathrm{N}_{\text {amide }} \rightarrow \mathrm{Cu}(\mathrm{II})\right)$.

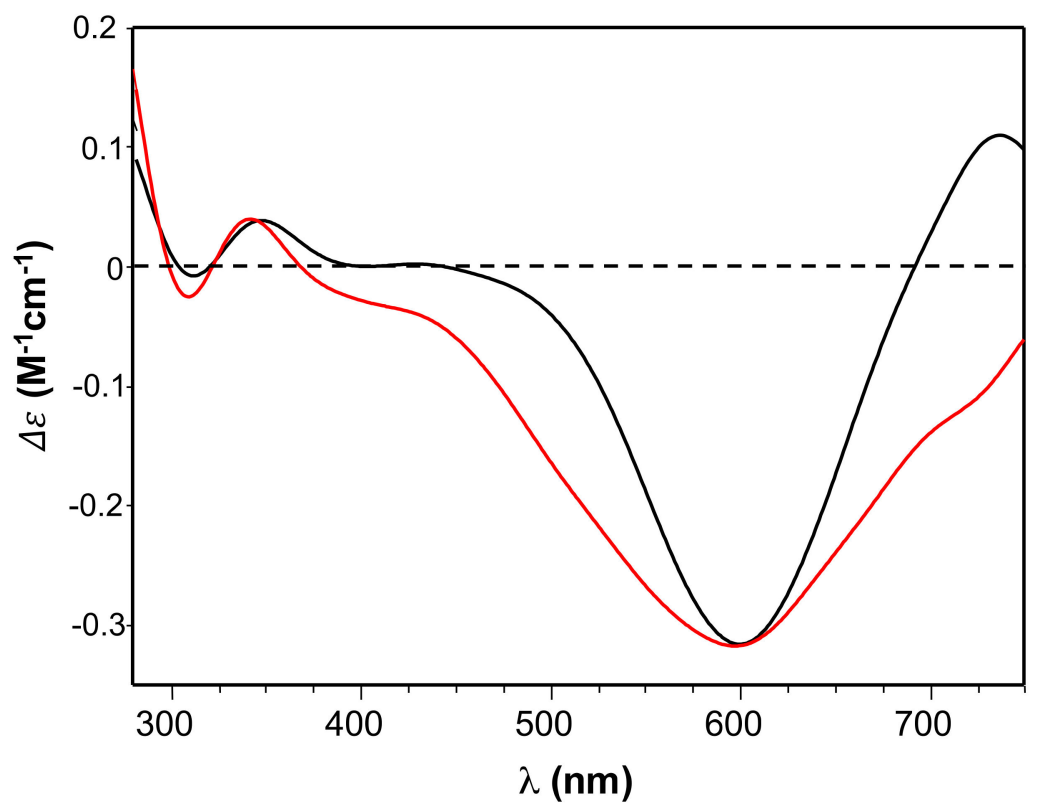

Figure 2. Circular dichroism (CD) spectra of $\mathrm{Ang}_{60-68}+\mathrm{CuSO}_{4}$ (black line) and Ang ${ }_{60-68} \mathrm{Cys}+\mathrm{CuSO}_{4}$ (red line) at $\mathrm{pH}=7.4$. Equimolar concentration of peptide and copper were used: $[$ peptide $]=[\mathrm{Cu}(\mathrm{II})]=$ $1 \times 10^{-3} \mathrm{M}$. 
2.2. Biological Characterisation of the Interaction between Peptides- or Protein-NP Conjugates and Brain Tumour (A172 line) or Non-Tumour (d-SH-SY5Y) Cells

2.2.1. Determination of Angiogenin Expression in Glioblastoma (A172), Undifferentiated and Differentiated Neuroblastoma (SH-SY5Y) Cell Lines

To analyse the endogenous levels of ANG expression in the tested cancer cells (glioblastoma A172 and neuroblastoma SH-SY5Y) and neuronal-like cells (differentiated neuroblastoma, d-SH-SY5Y), we performed western blot analyses of protein extracts from crude cell lysates (Figure S1 in the Supplementary Material). Results confirmed that in tumour cells the expressed level of protein was significantly higher than in differentiated neuroblastoma (Figure S1a,b). Moreover, to control the specific interaction of anti-angiogenin antibody with Ang $60-68$ or Ang ${ }_{60-68}$ Cys in the comparison with ANG, the peptides and protein samples were analysed by Western and dot blotting assays. The used anti-angiogenin antibody detected only the whole protein but did not interact with the two peptide fragments (Figure S1c,d).

\subsubsection{Cell Viability}

MTT (3-(4, 5-dimethylthiazolyl-2)-2, 5-diphenyltetrazolium bromide) assays were carried out to assess the effect on cell viability (Figure 3 ) of peptides- or protein-functionalised NPs, in the absence or presence of copper ions, for brain glioblastoma (A172 line) and differentiated neuroblastoma (d-SH-SY5Y), respectively.

(a)

$$
\square \text { w/o Cu (II) }
$$

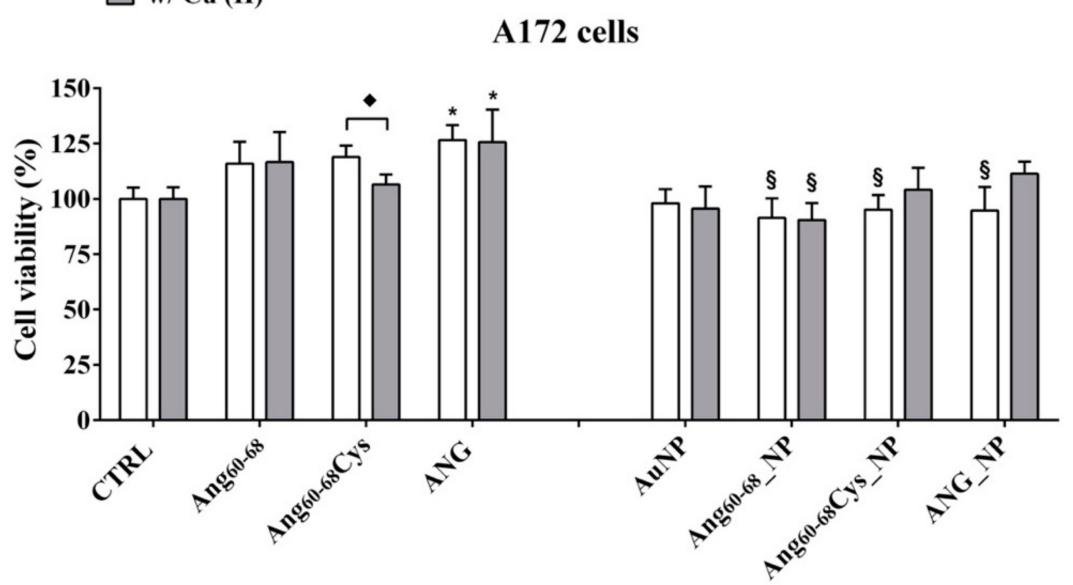

Figure 3. Cont. 
(b)

$$
\begin{aligned}
& \square \text { w/o Cu (II) } \\
& \square \text { w/ Cu (II) }
\end{aligned}
$$

\section{Differentiated SH-SY5Y cells}

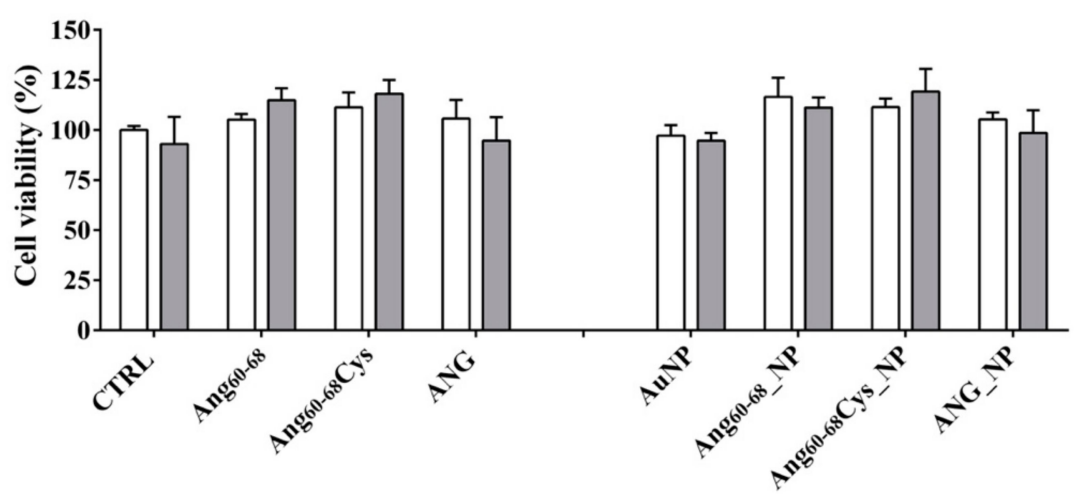

Figure 3. Cell viability determined by 3-(4, 5-dimethylthiazolyl-2)-2, 5-diphenyltetrazolium bromide (MTT) assay of A172 (a) and d-SH-SY5Y (b) cell lines. Cells were grown in basal culture medium (control: CTRL) and in culture medium supplemented with: Ang $60-68(30 \mu \mathrm{M}), \operatorname{Ang}_{60-68} \mathrm{Cys}(30 \mu \mathrm{M})$; ANG (100 nM), AuNP $\left(9.4 \mathrm{nM}=1.4 \times 10^{8} \mathrm{NP} / \mathrm{mL}\right), \operatorname{Ang}_{60-68} \mathrm{NP}\left(1.4 \mathrm{nM}=4.0 \times 10^{6} \mathrm{NP} / \mathrm{mL},\left[\mathrm{Ang}_{60-68}\right]\right.$ $\left.=2.8 \times 10^{-12} \mathrm{M}\right)$, Ang $_{60-68}$ Cys_NP $\left(1.4 \mathrm{nM}=4.0 \times 10^{6} \mathrm{NP} / \mathrm{mL},\left[\right.\right.$ Ang $_{60-68}$ Cys] $\left.=2.6 \times 10^{-12} \mathrm{M}\right)$, ANG_NP $\left(1.2 \mathrm{nM}=3.4 \times 10^{6} \mathrm{NP} / \mathrm{mL},[\mathrm{ANG}]=0.2 \times 10^{-12} \mathrm{M}\right)$. All conditions were evaluated in presence or absence of metal ions (copper sulphate: $\mathrm{Cu}(\mathrm{II}), 20 \mu \mathrm{M})$. The bars represent means $\pm \mathrm{SD}$ of three independent experiments performed in triplicate (S.D. = standard deviation). Statistically significant differences, determined by one-way analysis of variance ANOVA are indicated: ${ }^{*} p \leq 0.05$ versus CTRL; $\S p \leq 0.05$ versus the respective treatment with free peptides/protein; $p \leq 0.05$ versus the respective treatment w/o Cu(II).

In the tumour A172 cell line (Figure 3a), a significant increase on viability (+25\%; $p \leq 0.05$ vs. control untreated cells) was found after the treatment with ANG, both in absence and in the presence of added $\mathrm{Cu}(\mathrm{II})$. The cells incubation either with free peptides of $\mathrm{Ang}_{60-68} \mathrm{Cys}$ or $\mathrm{Ang}_{60-68}$ did not induce any significant change on cell viability; similar results were found for cells treated with peptides in the presence of copper. As to nanoparticle-treated cells, the incubation with bare AuNP, both in the absence and with $\mathrm{Cu}(\mathrm{II})$, did not modify the cell viability in comparison with control cells. The incubation with Ang $_{60-68 \_N P}$ reduced the cell viability by about $20-25 \%$ ( $p \leq 0.05$ vs. the respective peptide and peptide $+\mathrm{Cu}(\mathrm{II})$ controls), both in the absence and in the presence of copper. As to Ang $60-68$ Cys_NP, a significant cell viability decrease in the absence of $\mathrm{Cu}(\mathrm{II})(-25 \% ; p \leq 0.05 \mathrm{vs}$. the respective free peptide) was nullified by the incubation in presence of copper. A similar trend was found for the cells incubated with ANG_NP, where a reduced cell viability $(-20 \% ; p \leq 0.05$ vs. the respective free protein) in the absence of copper but no significant difference in presence of copper were found.

In the non-tumour d-SH-SY5Y cell line (Figure 3b), none of the treatments used resulted in a statistically significant decrease of cell viability in comparison to untreated control cells. Trypan blue staining confirmed the above reported results (data not shown).

\subsubsection{Cytoskeleton Actin Reorganisation and Intranuclear Angiogenin}

Cell migration is a critical step in tumour invasion and metastasis; the regulation of this process is often monitored in therapies for treating cancer. Reorganization of the actin cytoskeleton is the primary mechanism of cell motility and is essential for most types of cell migration [49].

Confocal laser scanning microscopy (LSM) demonstrated substantial differences between the tumour A172 (Figure 4) and non-tumour d-SH-SY5Y (Figure 5) cell lines in the organization of the actin 
cytoskeleton, both before and after the treatments with the peptides/protein-conjugated nanoparticles, as well as the incubation in the copper-supplemented medium.

Combined staining for F-actin (green) and nuclei (blue) for untreated glioblastoma (Figure 4, panel 1, CTRL) clearly shows their polygonal shape along with different types of actin dorsal fibres and transverse arcs, typical for the lamellipodial actin meshwork [50]. The cell treatment with bare AuNP and/or the addition of $\mathrm{Cu}$ (II) (Figure 4, panels 2-4) increased actin stress fibres. In contrast to A172 cells, F-actin staining of untreated d-SH-SY5Y cells (Figure 5, panel 1, CTRL) analysed by Laser Scanning Confocal Microscopy (LSM) showed several distinct types of actin structures with broad leading edges, including a lamellipodium with a loose meshwork of actin filaments, an actin rich lamella, dorsal ruffles, transverse arcs and stress fibres, as expected for differentiated neuroblastoma [51].

A172 cells treated with the free peptides or protein showed a diffuse actin staining for several lamellipodia protruding from the cell body in all directions. The addition of copper did not change

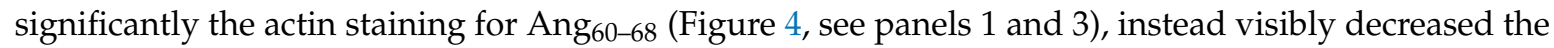
lamellipodia structures for Ang ${ }_{60-68}$ Cys (Figure 4, panels 1 and 3) and ANG (Figure 4, panels 1 and 3), respectively. Both in absence and in the presence of copper, A172 cells treated with Ang $60-68$ NP (Figure 4, panels 2 and 4) and ANG_NP (Figure 4, panels 2 and 4) still displayed a similar actin staining than those incubated with the free peptide or protein, respectively.

On the contrary, after incubation with Ang ${ }_{60-68} \mathrm{Cys}_{-} \mathrm{NP}$, both in the absence and presence of copper (Figure 4, panels 2 and 4), cells contained very few, if any, actin stress fibres in the central regions and lamellipodia structures.

For d-SH-SY5Y cells treated with the two peptides or the protein or their nanoparticle conjugates, irrespective of the incubation in copper-supplemented medium or not, the most notable change was a generally less dense meshwork of actin filaments after the treatment with Ang $60-68$ (Figure 5, panels 1-4) or Ang ${ }_{60-68}$ Cys (Figure 5, panels 1-4). The central region of these cells contained neither ventral stress fibres nor dorsal ruffles or transverse arcs detectable by LSM. On the contrary, numerous and diffuse actin structures, as well as prominent actin stress fibres along the entire cell border were found for cells treated with ANG samples (Figure 5, panels 1-4).

LSM imaging of intracellular angiogenin in glioblastoma and differentiated neuroblastoma cells confirmed the western blot results (see Figure S1) that untreated non-tumour d-SHSY5Y cells (Figure 5, panel 5) showed lower levels of endogenous ANG in the cytoplasm and in the nucleus than untreated tumour A172 cells (Figure 4, panel 5).

Cells incubated with ANG for $2 \mathrm{hr}$ exhibited a strong increase of the red staining, confirming the cellular uptake of exogenous angiogenin. In A172 cells the staining was especially enhanced in the presence of copper ions for the nuclear and perinuclear regions (Figure 4, panels 7,8). In d-SH-SY5Y cells, an increased red staining was visible in vesicles in the cytoplasm and in the neurites (Figure 5, panels 5-8), according to intracellular angiogenin localisation reported by Thiyagarajan et al. in similar neuronal cell lines [52]. We also observed the presence of intense punctuate structure of angiogenin in perinuclear and neurite regions, suggesting formation of resembling secretory granules.

Noteworthily, A172 cells treated with the peptide fragments Ang $60-68$ (Figure 4, panels 5-8) or Ang ${ }_{60-68}$ Cys (Figure 4, panels 5-8) showed a diffuse cytoplasmic staining and a weak staining in the nucleus, neurites and cell membrane. A negligible staining of nuclear angiogenin was found after cell incubation with peptide-conjugated nanoparticles in the presence of copper ions. 


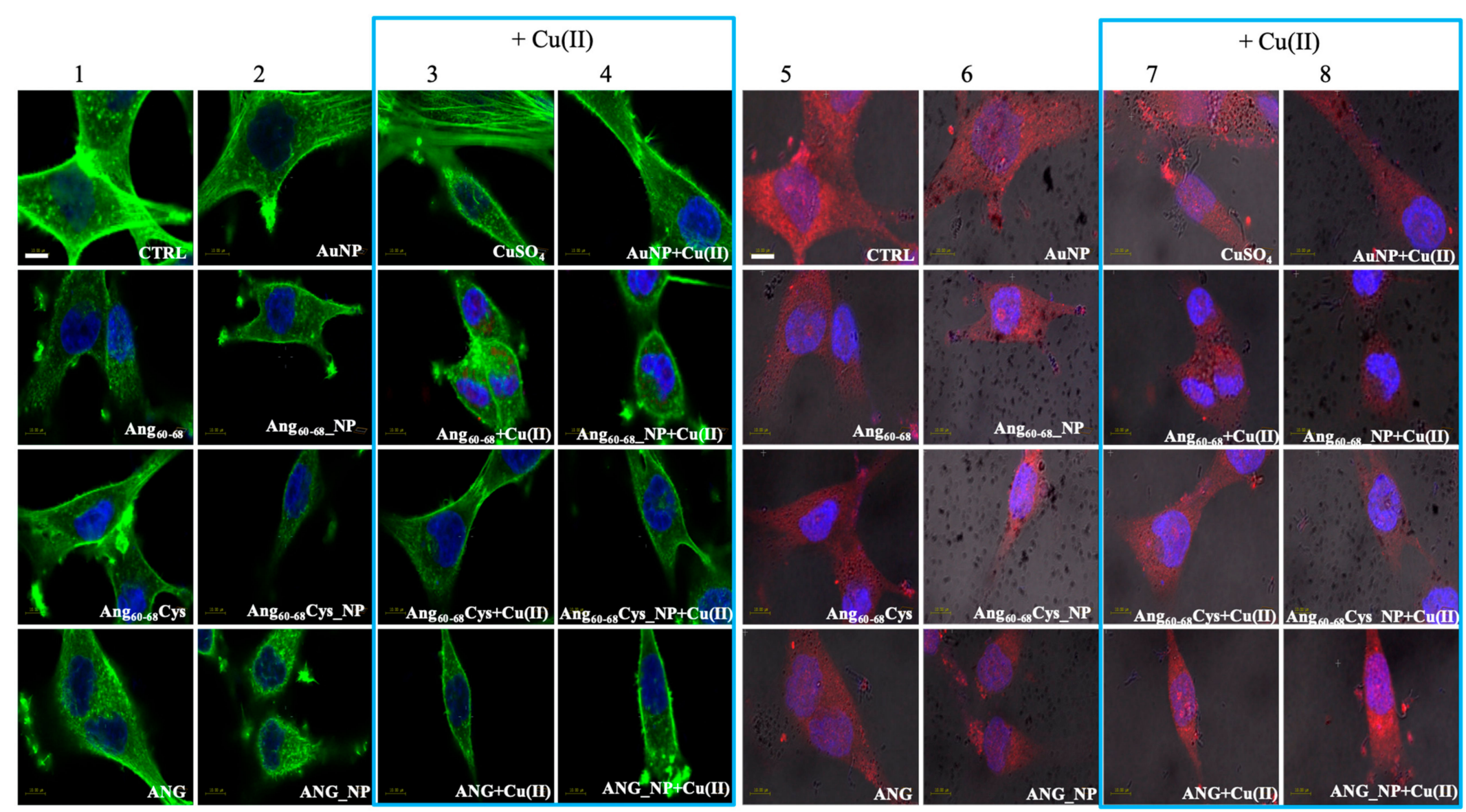

Figure 4. Confocal micrographs of A172 cells. Actin Green ${ }^{\circledR} 488$ (in green, ex/em $=488 / 500-530 \mathrm{~nm}$ ) and Hoechst33342 (in blue, ex/em=405/425-475 nm) were used as F-actin and nuclear markers, respectively. Antibody against angiogenin shows angiogenin localisation in red (ex/em=543/560-700 $\mathrm{nm}$ ) and micrographs are merged with optical bright field images (in grey). Before treatments, cell were rinsed with fresh culture medium and incubated for $2 \mathrm{~h}$ with basal culture medium (control: CTRL) and in culture medium supplemented with: Ang $60-68(30 \mu \mathrm{M})$, Ang ${ }_{60-68}$ Cys $(30 \mu \mathrm{M})$; ANG $(100 \mathrm{nM})$, AuNP $\left(9.4 \mathrm{nM}=1.4 \times 10^{8} \mathrm{NP} / \mathrm{mL}\right)$, Ang $60-68 \_\mathrm{NP}(1.4 \mathrm{nM}$ $\left.=4.0 \times 10^{6} \mathrm{NP} / \mathrm{mL},\left[\mathrm{Ang}_{60-68}\right]=2.8 \times 10^{-12} \mathrm{M}\right)$, Ang $_{60-68}$ Cys_NP $\left(1.4 \mathrm{nM}=4.0 \times 10^{6} \mathrm{NP} / \mathrm{mL},\left[\mathrm{Ang}_{60-68} \mathrm{Cys}\right]=2.6 \times 10^{-12} \mathrm{M}\right)$, ANG_NP $\left(1.2 \mathrm{nM}=3.4 \times 10^{6} \mathrm{NP} / \mathrm{mL}\right.$, $\left.[\mathrm{ANG}]=0.2 \times 10^{-12} \mathrm{M}\right)$. Scale bar $=10 \mu \mathrm{m}$. 


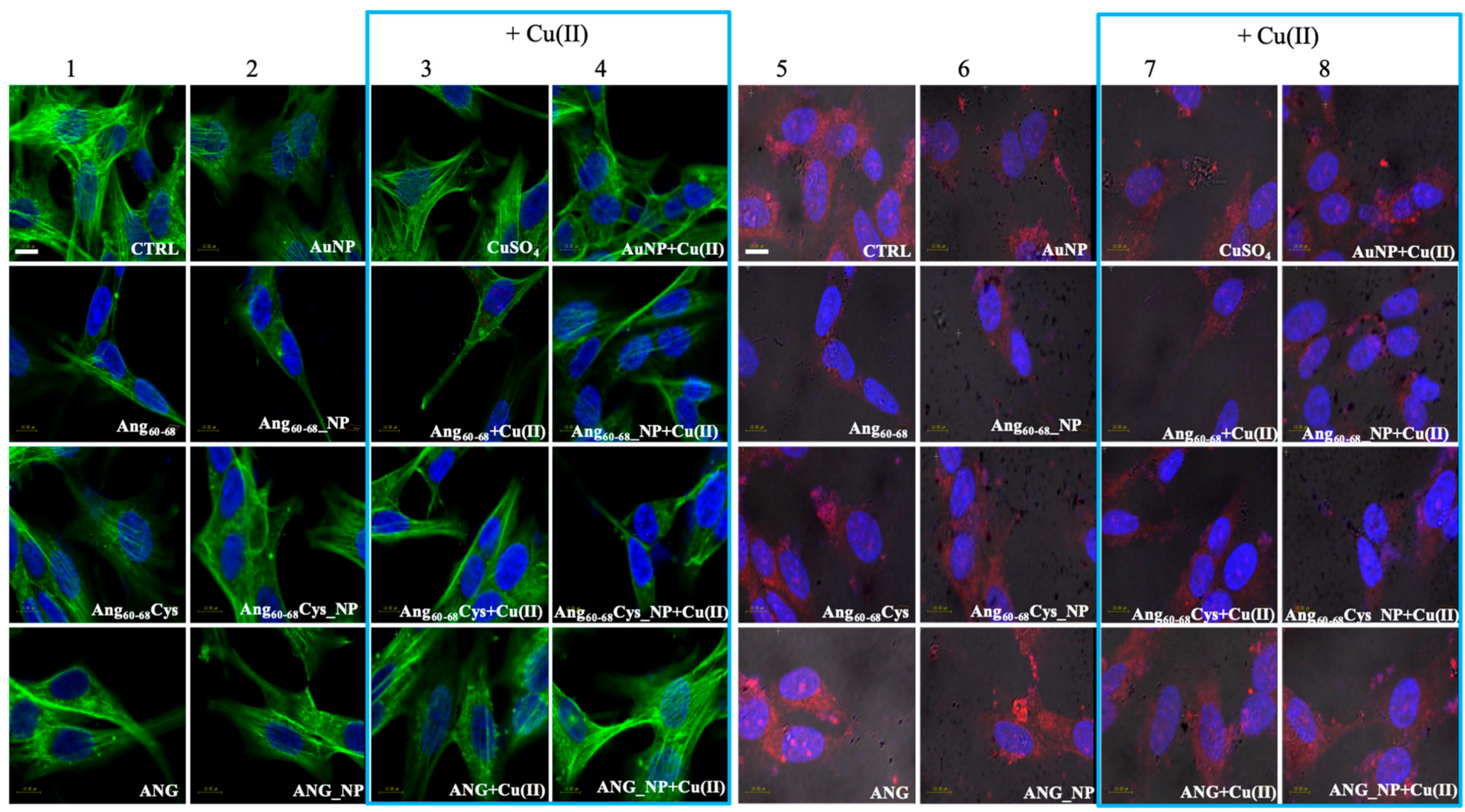

Figure 5. Confocal micrographs of d-SH-SY5Y cells Actin Green ${ }^{\circledR} 488$ (in green, ex/em $=488 / 500-530 \mathrm{~nm}$ ) and Hoechst33342 (in blue, ex/em $=405 / 425-475 \mathrm{~nm}$ ) were used as F-actin and nuclear markers, respectively. Antibody against angiogenin shows angiogenin localisation in red (ex/em=543/560-700 nm) and micrographs are merged with optical bright field images (in grey). Before treatments, cell were rinsed with fresh culture medium and incubated for $2 \mathrm{~h}$ with basal culture medium (control: CTRL) and in culture medium supplemented with: Ang $60-68(30 \mu \mathrm{M}), \mathrm{Ang}_{60-68} \mathrm{Cys}(30 \mu \mathrm{M})$; ANG $(100 \mathrm{nM}), \mathrm{AuNP}\left(9.4 \mathrm{nM}=1.4 \times 10^{8} \mathrm{NP} / \mathrm{mL}\right), \mathrm{Ang} 60-68 \_\mathrm{NP}$ $\left(1.4 \mathrm{nM}=4.0 \times 10^{6} \mathrm{NP} / \mathrm{mL},\left[\mathrm{Ang}_{60-68}\right]=2.8 \times 10^{-12} \mathrm{M}\right)$, Ang $_{60-68} \mathrm{Cys} \_\mathrm{NP}\left(1.4 \mathrm{nM}=4.0 \times 10^{6} \mathrm{NP} / \mathrm{mL},[\right.$ Ang $\left.60-68 \mathrm{Cys}]=2.6 \times 10^{-12} \mathrm{M}\right), \mathrm{ANG} \_\mathrm{NP}\left(1.2 \mathrm{nM}=3.4 \times 10^{6}\right.$ $\left.\mathrm{NP} / \mathrm{mL},[\mathrm{ANG}]=0.2 \times 10^{-12} \mathrm{M}\right)$. Scale bar $=10 \mu \mathrm{m}$. 


\subsubsection{VEGF Release and Synthesis}

VEGF has been identified as the most important pro-angiogenic factor released by cancer cells and its concentration in the tissue of glioblastomas has been demonstrated significantly higher than that in normal brain [53]. Moreover, VEGF has a crucial role in neurogenesis, neuronal patterning, neuroprotection and glial growth $[30,54]$. Figure 6 shows the VEGF release after incubation for $24 \mathrm{~h}$ of tumour A172 cells and d-SH-SY5Y with peptides- or protein-conjugated NPs, in the absence or presence of copper ions.

(a)

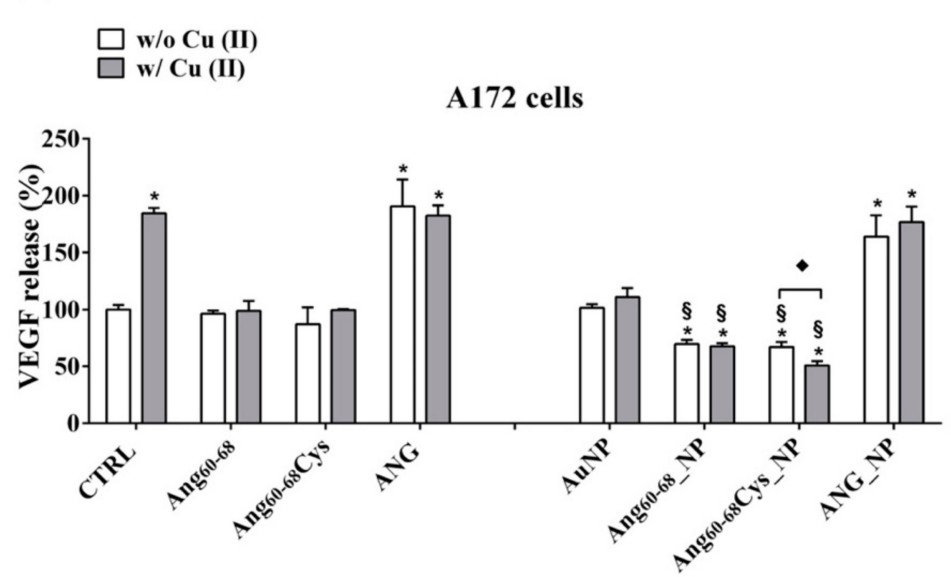

(b)

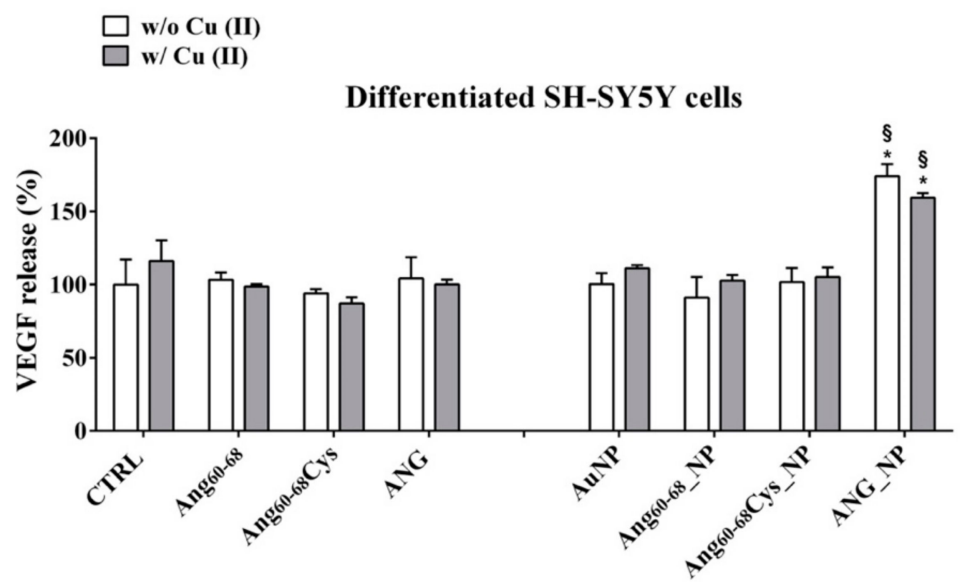

Figure 6. Vascular endothelial growth factor (VEGF) release in the medium of confluent cultures of A172 (a) and differentiated d-SH-SY5Y cells (b). Cells were grown in basal culture medium (control: CTRL) and in culture medium supplemented with: Ang ${ }_{60-68}(30 \mu \mathrm{M})$, Ang $_{60-68} \mathrm{Cys}(30 \mu \mathrm{M})$; ANG $(100 \mathrm{nM}), \operatorname{AuNP}\left(9.4 \mathrm{nM}=1.4 \times 10^{8} \mathrm{NP} / \mathrm{mL}\right), \mathrm{Ang}_{60-68} \mathrm{NP}\left(1.4 \mathrm{nM}=4.0 \times 10^{6} \mathrm{NP} / \mathrm{mL},\left[\right.\right.$ Ang $_{60-68}$ ] $=$ $\left.2.8 \times 10^{-12} \mathrm{M}\right)$, Ang ${ }_{60-68}$ Cys_NP $\left(1.4 \mathrm{nM}=4.0 \times 10^{6} \mathrm{NP} / \mathrm{mL}\right.$, [Ang $\left.\left.{ }_{60-68} \mathrm{Cys}\right]=2.6 \times 10^{-12} \mathrm{M}\right)$, ANG_NP $\left(1.2 \mathrm{nM}=3.4 \times 10^{6} \mathrm{NP} / \mathrm{mL}\right.$, [ANG] $\left.=0.2 \times 10^{-12} \mathrm{M}\right)$. All conditions were evaluated in presence or absence of metal ions (copper sulphate: $\mathrm{Cu}(\mathrm{II}), 20 \mu \mathrm{M}$ ). Sandwich enzyme-linked immunosorbent assay (ELISA) with monoclonal anti-VEGF antibody was used. The bars represent means \pm SD of three independent experiments performed in triplicate (S.D. = standard deviation). Statistically significant differences, determined by one-way analysis of variance ANOVA are indicated: ${ }^{*} p \leq 0.05$ versus $\mathrm{CTRL} \S^{\S} p \leq 0.05$ versus the respective treatment with free peptides/protein; ${ }^{\star} p \leq 0.05$ versus the same treatment $\mathrm{w} / \mathrm{o} \mathrm{Cu}$ (II). 
In A172 cells (Figure 6a) the treatments with copper alone increased the VEGF release by about 2.0 folds ( $p \leq 0.05$ vs. control untreated cells), confirming the relevant role of this cation in cancer progression [55].

The incubation of the cells with Ang ${ }_{60-68}$ Cys or with Ang ${ }_{60-68}$ did not modify the VEGF release in comparison to control cells, both in the absence and in the presence of $\mathrm{Cu}(\mathrm{II})$ whereas the treatments with ANG or ANG $+\mathrm{Cu}$ (II) increased the VEGF release by about 2.3 -fold ( $p \leq 0.05$ vs. control untreated cells).

The treatments with bare AuNP, both in the absence and in the presence of copper ions, did not significantly modify the VEGF release in comparison to control cells. Surprisingly, the incubation with AuNPs functionalized with peptide fragment Ang ${ }_{60-68}$ Cys and Ang $60-68$, induced a significant reduction of VEGF release respectively by $27 \%$ and by $30 \%$, in comparison to the corresponding control (free $\mathrm{Ang}_{60-68} \mathrm{Cys}$ and free $\mathrm{Ang}_{60-68}$ ). Moreover, further reduction of the release was found when the incubation with peptide fragment $\mathrm{Ang}_{60-68}$ Cys was performed in presence of copper. No difference was found in VEGF release after treatment of A172 cells with ANG_NP in comparison to cells treated with free ANG.

The incubation of d-SH-SY5Y cells with ANG did not modulate the VEGF release, as well as with $\mathrm{Ang}_{60-68}$ and $\mathrm{Ang}_{60-68} \mathrm{Cys}$, both in absence and in presence of copper, in comparison to the respective controls.

Differently from A172 cells, in non-tumour d-SH-SY5Y cells (Figure 6b), only the treatment with AuNP functionalized with ANG, both in the absence and in presence of copper, induced an increase of the VEGF release in comparison to untreated control cells. The incubation of control cells with copper did not modulate the VEGF release. The concentration of VEGF released by A172 and d-SH-SY5Y was $133 \mathrm{pg} / \mathrm{mL} \pm 10.1$ and $58 \mathrm{pg} / \mathrm{mL} \pm 4.3$, respectively.

These results were confirmed by determination of VEGF messenger RNA (mRNA) levels (Figure 7). In A172 cells (Figure 7a) the treatments with ANG significantly increased mRNA transcription, whereas ANG_NP induced a significant reduction of transcription in comparison with free ANG but with values higher than control cells. No differences were found after treatment with free Ang ${ }_{60-68}$, free Ang ${ }_{60-68} \mathrm{Cys}$ as well as bare NPs. On the other hand, the incubation with Ang $60-68 \_N P$ and Ang $60-68$ Cys_NP induced a significant reduction of mRNA transcription by about 2.2 and 2.7 folds, respectively, in comparison to the respective control (free Ang $60-68$ and free $\mathrm{Ang}_{60-68}$ Cys). Moreover, further reduction of the transcription was found after incubation in the presence of copper.

In non-tumour d-SH-SY5Y cells (Figure 7b), only the treatment with AuNP functionalized with ANG, both in the absence and in presence of copper, induced an increase of the VEGF mRNA transcription in comparison to the respective control (free ANG). 
(a)

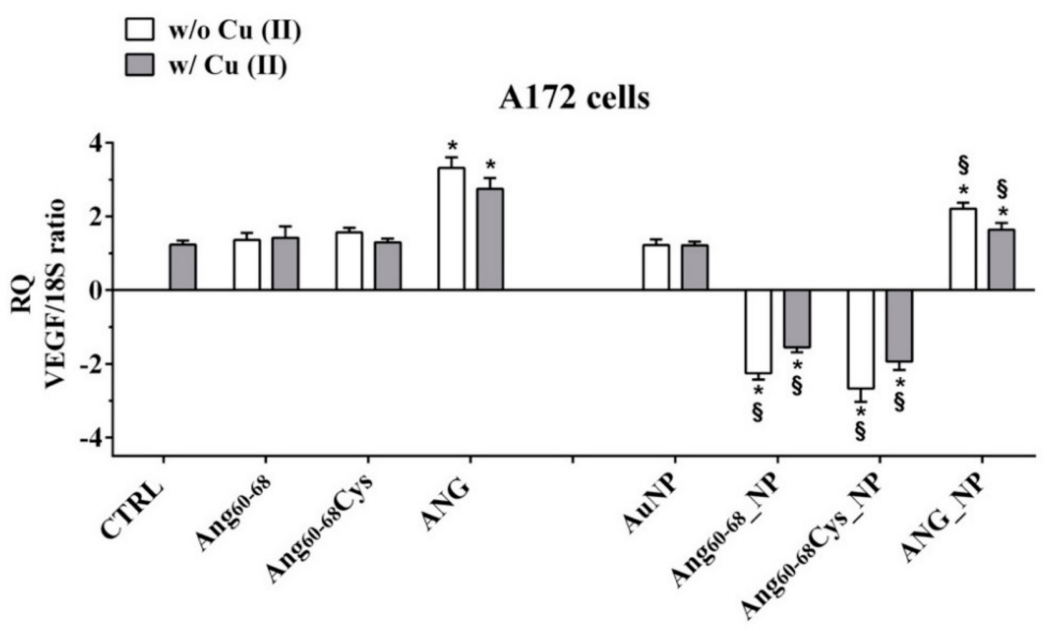

(b)

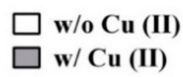

Differentiated SH-SY5Y cells

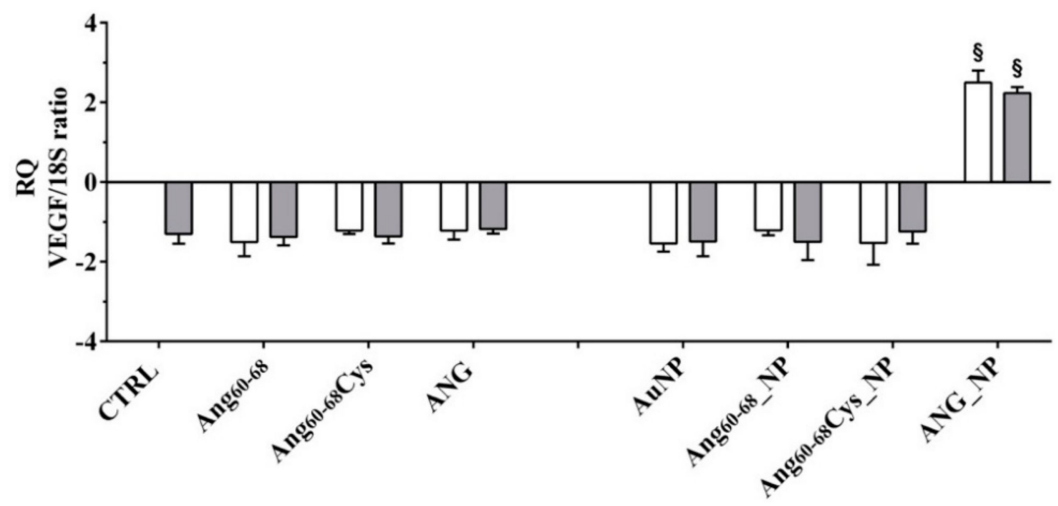

Figure 7. Vascular endothelial growth factor (VEGF) mRNA levels determination by qPCR in A172 (a) and differentiated d-SH-SY5Y cells (b). Cells were grown in basal culture medium (control: CTRL) and in culture medium supplemented with: Ang $60-68(30 \mu \mathrm{M})$, Ang ${ }_{60-68}$ Cys $(30 \mu \mathrm{M})$; ANG (100 nM), $\operatorname{AuNP}\left(9.4 \mathrm{nM}=1.4 \times 10^{8} \mathrm{NP} / \mathrm{mL}\right)$, Ang $_{60-68} \mathrm{NP}\left(1.4 \mathrm{nM}=4.0 \times 10^{6} \mathrm{NP} / \mathrm{mL},\left[\mathrm{Ang}_{60-68}\right]=2.8 \times 10^{-12}\right.$ $\mathrm{M})$, Ang $_{60-68} \mathrm{Cys} \_\mathrm{NP}\left(1.4 \mathrm{nM}=4.0 \times 10^{6} \mathrm{NP} / \mathrm{mL}\right.$, [Ang $\left.\left.60-68 \mathrm{Cys}\right]=2.6 \times 10^{-12} \mathrm{M}\right), \mathrm{ANG} \_\mathrm{NP}(1.2 \mathrm{nM}$ $\left.=3.4 \times 10^{6} \mathrm{NP} / \mathrm{mL},[\mathrm{ANG}]=0.2 \times 10^{-12} \mathrm{M}\right)$. All conditions were evaluated in presence or absence of metal ions (copper sulphate: $\mathrm{Cu}(\mathrm{II}), 20 \mu \mathrm{M}$ ). Relative quantification is referred to untreated cells (CTRL). Data normalized with respect to the expression level of S18 mRNA. The bars represent means \pm standard deviation (SD) of three independent experiments performed in triplicate. Statistically significant differences, determined by one-way analysis of variance (ANOVA) are indicated: ${ }^{*} p \leq 0.05$ versus control; $\S p \leq 0.05$ versus the respective treatment with free peptides/protein.

\section{Discussion}

In this study, two brain cell lines, namely tumour glioblastoma (A172) and differentiated neuroblastoma (d-SH-SY5Y) neuron-like cells, were scrutinised after incubation with hybrid nanoassemblies made of gold nanoparticles functionalised with angiogenin protein or with two different angiogenin-mimicking peptides ( $\mathrm{Ang}_{60-68}$ and its cysteine derivative at the C-terminus, Ang $_{60-68}$ Cys) containing the ANG residues from 60 to 68 , which is the the exposed protein loop region that is part of a cell-surface receptor binding site [56]. 
The Ang $60-68$ peptide has been demonstrated to specifically interact with cytoskeleton actin [6], whereas the Ang ${ }_{60-68}$ Cys peptide has been successfully used to tailor gold nanoparticles by chemical grafting [44]. Gold, indeed, being a soft acid, binds to soft bases like thiols, to form stable Au-S bonds $(40-50 \mathrm{kcal} / \mathrm{mol})$ that are able to replace the citrate shell on the nanoparticle surface due to the strong affinity binding of the thiol groups with the metal [57].

In a previous study, we scrutinised the actual immobilisation of $\mathrm{Ang}_{60-68} \mathrm{Cys}$ and Ang $60-68$ onto the surface of AuNPs upon the simple addition of the peptide solution to nanoparticles dispersed in water. Indeed, by a multitechnique characterisation approach, including UV-visible, attenuated total reflectance-Fourier transform infrared (ATR/FTIR) and circular dichroism (CD) spectroscopies as well as atomic force microscopy(AFM), we could demonstrate an irreversible strong interaction between the peptide molecules and the gold nanoparticles resulting into the biomolecule-coated nanoparticles [44]. In the present work, to functionalize the gold nanoparticles with Ang $60-68$, Ang ${ }_{60-68}$ Cys or ANG, the biomolecules were added to the colloidal dispersion $\left(1.7 \times 10^{8} \mathrm{AuNP} / \mathrm{mL}\right)$ at the concentration respectively of $3 \times 10^{-5} \mathrm{M}$ for the peptides and $1 \times 10^{-7} \mathrm{M}$ for the protein, and the shifts in the plasmon band were monitored (Figure 1).

The optical interface established between the biomolecules and the metal nanoparticle surface, as investigated by UV-visible spectroscopy, clearly evidenced an irreversible immobilisation of the peptides and protein molecules onto AuNPs (Figure 1d).

Noteworthy, a red-shift in the wavelength of maximum absorption $\left(\lambda_{\max }\right)$ as well as a broadening in the FWHM of the plasmon peak were found for both peptides- and protein-added nanoparticles in comparison to bare AuNPs. These spectral changes point to an increase in the nanoparticle optical size, which is dependent on the following two concomitant processes: (i) nanoparticle surface decoration by biomolecules adsorption; (ii) nanoparticles aggregation.

The latter contribution was most evident for the protein, as displayed by the plasmon peak broadening and the appearance of a shoulder approximately at $600 \mathrm{~nm}$ of wavelength. Hence, the NP functionalisation by the biomolecules immobilisation resulted in peptide-conjugated NPs with lower tendency to aggregation than the protein-conjugated NPs. To better understand these findings, the nanoparticle coverage $\left(\Gamma\right.$, in molecule/NP) was calculated from the changes in $\lambda_{\max }$ by using equations (1), (2) and (3).

Theoretical predictions show how the local refractive index environment of a metal nanoparticle affects its absorption spectrum. By assuming the protein-coated nanoparticles as core-shell spheres with a metallic core of $d$ diameter, corresponding to the uncoated nanoparticles, and a homogeneous spherical proteinaceous shell, the fraction of protein over the total particle, $g$, is related to the changes in the wavelength of maximum absorption for uncoated colloid $\left(\lambda_{\max , 0}\right)$, as given by Equation (1):

$$
g=\left(1+\alpha_{s}\right)\left(\frac{\lambda_{p}^{2}\left(\varepsilon_{s}-\varepsilon_{m}\right)}{\Delta \lambda \cdot \lambda_{\max , 0}}+2 \alpha_{s}\right)^{-1},
$$

where $\lambda_{p}$ is the free electron oscillation wavelength (which is $131 \mathrm{~nm}$ for gold [58]), $\varepsilon$ is a dielectric constant or relative permittivity (equal to the squared refractive index); $\alpha_{s}=\frac{\left(\varepsilon_{s}-\varepsilon_{m}\right)}{\left(\varepsilon_{s}+2 \varepsilon_{m}\right)}$ is the polarizability of a sphere with shell dielectric constant $\varepsilon_{s}$ in a surrounding medium of dielectric constant $\varepsilon_{m}$. According to Equation (2), which refers to the shell thickness (s):

$$
s=\frac{d}{2}\left[\frac{1}{[1-g]^{1 / 3}}-1\right],
$$

and using the Feijter's formula in Equation (3):

$$
\Gamma=s \frac{n_{s}-n_{m}}{d n / d c}
$$


where $\Gamma$ is the coverage and $d n / d c$ is the refractive index increment (typically $0.19 \mathrm{~mL} \cdot \mathrm{g}^{-1}$ for a protein [59]), the mass of protein absorbed per unit area can be calculated.

The estimated values from the experimental spectroscopic data as well as the theoretical coverage calculated by considering an ideal monolayer in the two limit configurations respectively of end-on or side-on, are given in Table 2.

Table 2. Protein fraction shell value $(g)$ and peptide/protein coverage $(\Gamma)$ calculated from the changes in the wavelength of maximum absorption $\left(\lambda_{\max }\right)$ of AuNP plasmon peak for peptide/protein added nanoparticles. The ideal monolayer coverage of the peptide/protein in the end-on and side-on limit configuration are given for comparison.

\begin{tabular}{|c|c|c|c|c|c|}
\hline \multirow[t]{2}{*}{ Sample } & \multirow[t]{2}{*}{$g^{(1)}$} & \multirow[t]{2}{*}{$\Gamma\left(\mathrm{ng} / \mathrm{cm}^{2}\right)$} & \multirow{2}{*}{$\begin{array}{c}\Gamma^{(2)} \\
(\text { molecules/NP) }\end{array}$} & \multicolumn{2}{|c|}{$\begin{array}{c}\text { Ideal Monolayer Coverage (3) } \\
\text { (molecules/NP) }\end{array}$} \\
\hline & & & & End-on & Side-on \\
\hline Ang $_{60-68 \_N P}$ & 0.74 & 79 & 194 & 177 & 83 \\
\hline Ang $_{60-68}$ Cys_NP & 0.74 & 79 & 178 & 202 & 149 \\
\hline ANG_NP & 0.90 & 165 & 32 & 23 & 10 \\
\hline
\end{tabular}

${ }_{1}$ Values calculated from Equation (1) in Materials and Methods by considering the refractive index values $(n)$ at $550 \mathrm{~nm}$ of 1.335 for water [60] and 1.38 for a pure protein [59], respectively. ${ }^{2}$ Values calculated from Equation (3) in Materials and Methods, given the molecular weights (MW) of $1105.5 \mathrm{~g} / \mathrm{mol}$ for Ang $60-68,1209.3 \mathrm{~g} / \mathrm{mol}$ for Ang $_{60-68}$ Cys and 14,200 g/mol for ANG, respectively. ${ }^{3}$ Calculated by using the average molecular dimensions $\left(\right.$ in $\left.\mathrm{nm}^{3}\right)$ respectively of $(1.7 \times 1.5 \times 3.2)$ for Ang $60-68,(1.6 \times 1.4 \times 1.9)$ for CysAng $60-68$ [44], and $(7 \times 6.2 \times 3.2)$ for ANG [61].

From Table 2 is evident that a multilayer coverage can be presumed for ANG_NP, while most likely a monolayer in end-on configuration and a sub-monolayer coverage can be assumed for Ang $60-68$ NP and Ang ${ }_{60-68}$ Cys_NP, respectively. Hence, in the case of ANG, many protein molecules adsorbed at the nanoparticle surface and formed a 'thick' shell that could perturb the mechanism of electrostatic stabilisation for colloidal gold [3], thus explaining the partial aggregation measured in UV-visible spectra. As to the two peptide fragments, their smaller size lead to the formation of a thinner and stiffer shell around the nanoparticles than that formed by the protein molecules. This picture is further supported by the coverage calculated for the pellets recovered after the washing steps. Indeed, for ANG_Au pellet, a loss of unbound and/or weakly bound proteins of about $78 \%$ can be estimated by the protein fraction shell decrease to $g=0.5$, which corresponds to coating thickness and absorbed protein mass of $s=1.54 \mathrm{~nm}$ and $\Gamma=36 \mathrm{ng} / \mathrm{cm}^{2}$, respectively. On the other hand, for both Ang ${ }_{60-68} \mathrm{NP}$ and Ang ${ }_{60-68}$ Cys_NP pellets, the calculated values for the peptide shell are still $g=0.74, s=3.36$ $\mathrm{nm}$ and $\Gamma=79 \mathrm{ng} / \mathrm{cm}^{2}$. To note, even if the measured plasmon peak changes were comparable upon their approaching at the interface with the gold nanoparticles, the cysteine residue in $\mathrm{Ang}_{60-68} \mathrm{Cys}$ is expected to drive, through the thiol-gold bonding [44], a more ordered and compact biomolecule gathering at the nanoparticle surface in comparison to Ang $60-68$, which is in agreement with the estimation of a sub-monolayer coverage in $\mathrm{Ang}_{60-68} \mathrm{Cys} \_\mathrm{NP}$.

The DLS method is a reliable instrumental tool for non-perturbative and sensitive diagnostics of the aggregation processes of gold nanoparticle conjugates initiated by biospecific interactions on their surface [62]. Indeed, the nanoparticle hydrodynamic size determined by DLS (Table 1) showed the same trend of optical size change; moreover, also evidenced nanoparticles aggregation induced by the addition of copper ions to the peptides- or protein-functionalised NPs (i.e., hydrodynamic size increase approximately of $373 \%, 866 \%$ and $15 \%$ for Ang $60-68 \_N P, A_{60}{ }_{60}$ Cys_NP and ANG_NP, respectively) but no size change for the bare AuNPs.

Transition metals, such as copper, can prompt the aggregation of proteins and peptides through the formation of metal complexes [63]. It is known that ANG is able to bind to copper ions [43] and bridged copper complexes can lead to the formation of nanoparticles clusters. This effect was more evident for the hybrids CysAng ${ }_{60-68}$ NP, where the prevalent chemisorption process leads to a more ordered arrangement of the biomolecules around the nanoparticles. 
The differences found in the presence of copper ions could also be due to different binding modes between the copper and the peptides- or the protein-functionalised nanoparticles. The UV-visible parameters of copper complexes formed by $\mathrm{Ang}_{60-68}$ and $\mathrm{Ang}_{60-68}$ Cys were similar, suggesting that the metal ion experiences the same coordination environment with both peptides. However, the observed blue-shift $(\Delta \lambda=6 \mathrm{~nm})$ and the parallel decrease of molar absorbance coefficient $(\Delta \varepsilon=10)$ for $\mathrm{Ang}_{60-68} \mathrm{Cys}+\mathrm{Cu}(\mathrm{II})$ compared to $\mathrm{Ang}_{60-68}+\mathrm{Cu}(\mathrm{II})$, suggest a slight increase of ligand field strength and a more planar disposition of donor atoms bound to the metal ion $[64,65]$.

The CD spectra (Figure 2) confirmed the involvement of imidazole and deprotonated amide nitrogen as donor atoms in metal binding for copper complexes formed by the two peptides [48]. The sharper peaks around $300 \mathrm{~nm}$ evidenced the slight increase of metal binding affinity of $\mathrm{Ang}_{60-68} \mathrm{Cys}$. Furthermore, the $C D$ broad band in the $d-d$ transition region suggested that the extra cysteine residue at C-terminus may affect peptide backbone conformation of $\mathrm{Ang}_{60-68}$ Cys more than it happens for Ang ${ }_{60-68}+\mathrm{Cu}$ (II) system [66]. As for the protein, the main copper anchoring sites are the RNase catalytic sites His-13 and His-114 [38]; therefore ANG displays a different coordination mode compared to copper complexes formed by $\mathrm{Ang}_{60-68}$ and $\mathrm{Ang}_{60-68}$ Cys. However, it has been hypothesized that in the presence of excess copper a second metal ion can bind to the 60-68 region of ANG affecting protein binding with cell membrane [37]. The different metal coordination modes may potentially tune the biological response of functionalized nanoparticles.

The tests of cell viability/proliferation, cytoskeleton actin, angiogenin translocation and VEGF release were scrutinised both in basal and in copper-conditioned medium. Noteworthy, copper is another co-player of the angiogenesis process $[33,34]$.

The cell response to nanoparticles is strongly dependent on the cell line, since, for instance, different cell models can overexpress different receptors at the membrane that may trigger the nanoparticle internalisation. ANG stimulates the expression of ANG receptors which mediate its nuclear translocation [16,28]; when nuclear translocation of ANG is inhibited, its angiogenic activity is abolished [67].

Neuroblastoma SH-SY5Y cells are used as a model of dopaminergic neurons as the cells possess similar biochemical functionalities of neurons. They are able to synthesize dopamine and also express dopamine transporter on the cell membrane [68]. On the other hand, SH-SY5Y cells have very low levels of the redox protein thioredoxin that together with glutathione redox cycle represents the major cellular redox buffer [69], acts as a growth factor and is found to be overexpressed in many human primary cancers including glioblastoma cells [70].

As to the cell viability effects measured on tumour glioblastoma (A172) and non-tumour differentiated neuroblastoma (d-SH-SY5Y) cell lines, our results (Figure 3) pointed to the very promising potentialities of peptide- and protein-functionalised gold nanoparticles to decrease the proliferation of tumour cells.

Indeed, after $24 \mathrm{~h}$ of A172 cells incubation with Ang $60-68 \_N P, \mathrm{Ang}_{60-68} \mathrm{Cys}$ _NP and ANG_NP a significantly decreased viability was found compared the cells treated with the free peptides or protein molecules as well as to the untreated control. Noteworthy, at the used experimental conditions, the bare AuNPs as well as the free peptides were found to not affect the cell viability, whereas the free protein increased the viability in comparison to untreated cells, both in the absence and in the presence of copper ions. Another interesting cue was found in the experiments performed in copper-supplemented medium, where cell treatments with Ang $60-68$ Cys_NP+Cu(II) and ANG_NP + Cu(II) nullified the abovementioned decrease of cell viability, whereas for cells treatments with $\mathrm{Ang}_{60-68} \mathrm{NP}+\mathrm{Cu}(\mathrm{II})$ no significant differences were found with respect to Ang ${ }_{60-68}$ NP. These findings confirmed the higher capability in the copper binding for the $\mathrm{Ang}_{60-68}$ Cys- conjugated nanoparticles with respect to Ang $60-68-\mathrm{NP}$, as discussed above from CD results.

In contrast to A172 cells, no toxicity nor increase in viability was observed for any of the incubation conditions of differentiated neuroblastoma cells, as expected for not proliferating non-tumour cells. 
These findings further support the good potentialities of our peptides- and protein-conjugated NPs as cell specific, anti-angiogenic nanomedicine tools.

Angiogenin is a protein with an extreme positive charge $(\mathrm{pI}>10.5)$, thus generally can avidly bind the cellular membrane [71]. Indeed, ANG binds to the membrane surface actin of vessel endothelial cells and activate the matrix protease cascades.

In the cytosol, angiogenin encounters an endogenous inhibitor protein, known as ribonuclease inhibitor (RI), which binds to angiogenin to form a complex with a dissociation constant value in the low femtomolar range, stabilized largely by favourable Coulombic interactions, as RI is highly anionic [72]. It has been demonstrated that upregulating RI suppresses tumour growth and tumour microvessel density through suppression of ANG function [73].

In order to explain the different response of two neural lines, we analysed via confocal microscopy the remodelling of actin filaments as well as the ANG translocation induced by the peptides- or protein-conjugated NPs, both in the absence and in the presence of $\mathrm{Cu}$ (II) (Figures 4 and 5).

Our results in tumour A172 cell line showed that the cell treatment with bare AuNPs and/or the addition of $\mathrm{Cu}$ (II) significantly increased actin stress fibres, while after incubation either with the free Ang 60-68 peptide as well as its NP-conjugated derivative, an enhanced actin staining for several lamellipodia protruding from the cell body in all directions were found, with no significant changes observed in the presence of copper. A similar strong actin staining for lamellipodia in Ang ${ }_{60-68} \mathrm{Cys}$ peptide-and ANG protein-treated cells was instead decreased by the presence of copper. Finally, after incubation with Ang ${ }_{60-68} \mathrm{Cys}_{-} \mathrm{NP}$, both in the absence and presence of copper, cells contained very few, if any, actin stress fibres in the central regions and lamellipodia structures.

As to the non-tumour d-SHSY5Y cell line, no significant changes in the cytoskeleton actin were found for cell incubation in the presence or not of copper ions, but only a generally less dense actin meshwork after the treatment with Ang ${ }_{60-68}$ or Ang ${ }_{60-68}$ Cys samples. Numerous and prominent actin stress fibres along the entire cell border were found for cells treated with ANG samples.

As migration and, thus, infiltration of glioma cells is largely governed by reshaping the cytoskeleton, it is no surprise that the composition and organization of the cytoskeleton in glioma cells differs strongly from that of healthy brain cells, such as the neuron-like differentiated neuroblastoma cells. In a study on glioblastoma multiforme (GBM), the most lethal brain tumour, Memmel et al. found that inhibition of cell migration was associated with massive morphological changes and reorganization of the actin cytoskeleton [50].

ANG can interact with the actin, a protein able to form different polymeric structures inside the cells, which is essential to maintain the cell structure and motility [74]. The result of the binding to the actin is the inhibition of the polymerization with consequent changing of the cell cytoskeleton. These modifications play a fundamental role during proliferation of both endothelial and tumour cells [75]. The role of ANG in cell migration, necessary for tumour invasion and metastasis, has been confirmed by an important study which detected elevated levels of secreted and cell surface-bound ANG in highly invasive metastatic breast cancer cells. It has been indeed demonstrated that ANG interacts with the plasminogen activation system, thus increasing plasmin formation and cell migration of tumour cells [76].

Under physiologic conditions, ANG is present in the nucleus and in the cytoplasm, where is held in an inactive state through interaction with its known inhibitor Ribonuclease/Angiogenin Inhibitor 1 (RNH1), which prevents random cleavage of cellular RNA. A minor pool of ANG is secreted and is internalized by surrounding cells with a mechanism of endocytosis receptor mediated (reviewed by Shawn [71]. In stressed cells ANG dissociates from his inhibitor and becomes active. In this condition, nuclear ANG translocates from nuclear to the cytoplasmic compartment where cleaves mature transfer ribonucleic acid (tRNA), releasing two smaller RNA fragments, termed $5^{\prime}$ - and $3^{\prime}$ tRNA-derived Stress-induced RNAs (tiRNAs). The post-transcriptional tRNA processing is necessary to allow the tRNA to regulate in specific manner the transcription [77]. Moreover, tRNA fragments can bind to cytochrome $\mathrm{c}$ and block the apoptosoma assembling, thereby inhibiting caspase-3, with consequent 
increasing of cell viability and proliferation [78]. Noteworthy, the nuclear concentration of ANG increases in the endothelial cells under the stimulation with basic fibroblast growth factor (bFGF), VEGF, acidic fibroblast growth factor (aFGF), epidermal growth factor (EGF), and foetal bovine serum (FBS).

Authors hypothesized that the endogenous angiogenin participates in endothelial cell proliferation induced by other angiogenic factors [29]. Recombinant ANG plays an important role in neuroprotection against excitotoxic and endoplasmic reticulum (ER) stress in primary motor neuron cultures, and in SOD1G93A mice [18].

By LSM we were able to visualise the different intracellular localisation of endogenous angiogenin in A172 and d-SH-SY5Y cells, but similar effects on angiogenin translocation or uptake by the treatment with the peptides- or protein-conjugated nanoparticles, respectively.

For tumour glioblastoma, we found the endogenous angiogenin localised in the nucleus and in the cytosol, while neuron-like differentiated neuroblastoma displayed a weaker angiogenin staining (according to western blotting analysis, Figure S1), mainly localised in cytoplasm. Indeed, A172 cells treated with the free protein or the protein-conjugated NPs exhibited a strong angiogenin staining of the nuclear and perinuclear regions, especially for incubation in copper-supplemented medium. In d-SH-SY5Y cells, most of the protein was visible in the cytoplasm as large speckles but is also present in the nucleus, in the neurites and the membrane. In both cell lines, upon the treatment with bare AuNPs and/or the incubation in copper-supplemented medium, structural perturbation of intracellular angiogenin was observed, with an intense punctuate structure in perinuclear and neurite regions that suggested the formation of resembling secretory granules.

The treatment with peptides or peptide-conjugated nanoparticles was able to translocate angiogenin, with a diffuse cytoplasmic staining and a weak staining in the nucleus, neurites and cell membrane after the incubation with $\mathrm{Ang}_{60-68}$ or Ang $\mathrm{A}_{60-68} \mathrm{Cys}$; in the presence of copper-supplemented medium, most of the protein remains in the cytoplasm and is absent from the neurites and membrane.

Nuclear angiogenin plays different roles. It is localised inside the nucleolus, centre of synthesis and assembly of the ribosomes, where stimulates rRNA production, required for cellular proliferation [79]. Moreover, ANG bind the histone protein and cause a modification which regulates mRNA transcription. The ability to bind the DNA allows to ANG to function as a adaptor protein which recruit other modifying enzymes with methyltransferase or acetyltransferase activity [16]. Moreover, ANG has a nuclear localization sequence (NLS), containing Arg 33, which equips the protein for nuclear import [28]. After entering the nucleus, ANG accumulates in the nucleolus, which is the site of ribosome biogenesis. Within the nucleolus, ANG stimulates ribosomal DNA (rDNA) transcription [80].

Our results demonstrate that ANG was able to enter glioma cells and to induce their proliferation. In A172 cancer cells, the mitogen activated protein kinase (MAPK)/extracellular-signal-regulated kinase (ERK) signalling pathway could be responsible of the ANG phosphorylation which prevent the binding with the RI. Consequently, free ANG could exercise his effect in the nucleus, promoting DNA transcription and cell proliferation [81]. The effect of ANG on A172 cells, but not of ANG_NP, was highlighted by the increase of VEGF transcription and release, after the ribonuclease activity of the protein in the nucleus.

The lower VEGF release after incubation of the cells with ANG_NP could be determined by the presence of NPs, which could prevent the phosphorylation of the protein, essential step for its nuclear translocation. A low concentration of phosphorylated protein could explain the reduction of VEGF release after incubation with ANG_NPs in comparison to free ANG.

The peptide fragments Ang $60-68$ Cys and Ang $60-68$ were able to enter the cells but only few of them could cross nuclear membranes, because they are missing of the nucleolar targeting, specifically of Arg 33; the consequent effect is a level of release of VEGF very similar to control cells. Instead, Ang $60-68$ Cys_NP and Ang $60-68 \_$NP entered the nucleus and successively they could bind rDNA. Probably, the fragments were not able to catalyse the digestion of the RNA on the promotor site, due to the lack of the catalytic sequence. Consequently, the dissociation of the transcription termination factor I-interacting protein (TIP5) from the rDNA promoter did not occur. The ensuing steric obstruction 
by the binding of Ang ${ }_{60-68} \mathrm{Cys} \_\mathrm{NP}$ and $\mathrm{Ang}_{60-68}$ NP to rDNA could block the binding of other native angiogenin molecules thereby significantly reducing rDNA transcription and VEGF production. The shield-effect of the NPs towards peptide fragments Ang ${ }_{60-68}$ Cys and Ang ${ }_{60-68}$ could represent an interesting strategy to modulate VEGF release by glioma cells.

The different response of the SH-SY5Y cells to ANG could depend by the interaction of the peptide with his inhibitor, as the signalling pathway determining the phosphorylation are switch off in not tumour cells. In this condition, the protein could remain inactive in the cytosol, bound to its inhibitor.

In differentiated SH-SY5Y cells, the hybrid ANG_NP increased VEGF release in comparison to free ANG probably because in absence of NPs, after the adhesion to- and crossing- through plasma membrane, it binds its inhibitor inside the cells. The hybrid ANG_NP protects the protein by the bind with the inhibitor, thereby increasing VEGF mRNA transcription and VEGF release in comparison to free ANG probably because the presence of the NPs could protect the protein by the binding with the inhibitor, thereby increasing VEGF mRNA transcription and VEGF release.

\section{Materials and Methods}

\subsection{Chemicals}

Gold(III) chloride trihydrate (CAS Number 16961-25-4), trisodium citrate dihydrate (CAS Number: 6132-04-3), 3-(N-morpholino)propanesulfonic acid (MOPS, 1132-61-2), potassium chloride (7447-40-7), sodium chloride (7647-14-5), tris(2-carboxyethyl)phosphine (TCEP, 51805-45-9), hydrochloric acid (7647-01-0), nitric acid (7697-37-2), sodium hydroxide (1310-73-2), N,N-diisopropyl-ethylamine (DIEA, 7087-68-5), N,N-dimethylformamide (DMF, $68-12-2), \quad 20 \% \quad(v / v)$ piperidine (110-89-4) in DMF solution, $N$-hydroxybenzotriazole (HOBt, 123333-53-9), triisopropylsilane (TIS, 6485-79-6), trifluoroacetic acid (TFA, 76-05-1), isopropyl $\beta$-D-1-thiogalactopyranoside (IPTG, 367-93-1), Tris(hydroxymethyl)aminomethane hydrochloride (Tris- $\mathrm{HCl}$ buffer, 1185-53-1), ethylenediaminetetraacetic acid (EDTA, 60-00-4), guanidine hydrochloride (GdnHCl), 1,4-dithiothreitol (DTT, 3483-12-3), phosphate buffered saline (PBS) tablets and 3-(4,5-dimethyl-2-thiazolyl)-2,5-diphenyl-2H-tetrazolium bromide (MTT, 298-93-1), ethylene glycol-bis(2-aminoethylether)- $N, N, N^{\prime}, N^{\prime}$-tetraacetic acid (EGTA, 67-42-5), nonyl phenoxypolyethoxylethanol (NP40, 9016-45 -9), bovine serum albumin (BSA), 3,3',5,5'-tetramethylbenzidine (TMB, 54827-17-7) sulphuric acid (7664-93-9) and Triton X-100 (9002-93-1) were purchased from Sigma-Aldrich (St. Louis, MO, USA). 2-(1-H-Benzotriazole-1-yl)-1,1,3,3-tetramethyluronium tetrafluoroborate (TBTU) was purchased from Novabiochem (Läufelfingen, Switzerland).

The designed primers for angiogenin (ANG) protein expression were purchased from Eurofins GWM (Ebersberg, Germany). The over-expression plasmid (pET22b(+)-ANG), including a codon-optimized gene for ANG, was obtained from Sloning BioTechnology (Puchheim, Germany). Terrific Broth (TB) liquid microbial growth medium, Dulbecco's modified eagle medium (DMEM), Ham's F-12 medium (F12), streptomycin, L-glutamine, foetal bovine serum (FBS) were provided by Lonza (Verviers, Belgium). DMEM high glucose 30-2002 was provided by ATCC (LGC Standards S.r.l., Sesto San Giovanni (MI), Italy). Ultrapure MilliQ water was used $\left(18.2 \mathrm{~m} \Omega \cdot \mathrm{cm}\right.$ at $25^{\circ} \mathrm{C}$, Millipore, (Burlington, MA, USA).

\subsection{Peptide Synthesis}

The fragment Ang $60-68$ including the amino acid sequence Ac-KNGNPHSEN-NH ${ }_{2}$ (molecular weight, MW, of $1105.5 \mathrm{~g} / \mathrm{mol}$, isoelectric point, PI, of 11.38), modified by $\mathrm{N}$-terminal acetylation and the C-terminal amidation, was assembled by using the solid phase peptide synthesis strategy, on an initiator+ Alstra ${ }^{\mathrm{TM}}$ fully automated microwave peptide synthesizer (Biotage, Uppsala, Sweden). The synthesis was performed on TGR resin $(0.25 \mathrm{mmol} / \mathrm{g})$ on $0.11 \mathrm{mmol}$ scale using a $30 \mathrm{~mL}$ reactor vial. The coupling reactions were carried out by using 5 -fold excess of amino acid, 5 equivalents of 
hydroxybenzotriazol/2-(1H-benzotriazole-1-yl)-1,1,3,3-tetramethylaminiumtetrafluoroborate/ $\mathrm{N}, \mathrm{N}$ diisopropylethylamine (HOBt/TBTU/DIEA) in $N, N$-dimethylformamide (DMF), under mixing for $10 \mathrm{~min}$ at room temperature. Fmoc deprotection steps were performed at room temperature by using $20 \%$ of piperidine in DMF for $15 \mathrm{~min}$. The N-terminal amino group was acetylated using a DMF solution containing acetic anhydride $(6 \% v / v)$ and DIEA $(5 \% v / v)$. The resin was washed with dichloromethane and dried on synthesizer. The peptide was purified by preparative reversed-phase chromatography (rp)-HPLC using a PrepStar 200 (model SD-1, Varian, Palo Alto, CA, USA) equipped with a Prostar photodiode array detector, with a protocol previously reported [48]. The peptide Ac-KNGNPHRENC-NH 2 (Ang ${ }_{60-68}$ Cys) was purchased from CASLO (Lyngby, Denmark).

\subsection{Protein Expression}

The human angiogenin expression was carried out following the method reported by Holloway et al. (2001) [82]. Briefly, the E. coli (BL21(DE3)) expression strain was cultured at $37^{\circ} \mathrm{C}$ under shaking (speed of 180 r.p.m.) in $5 \mathrm{~mL}$ of terrific broth (TB) (12 g peptone, $24 \mathrm{~g}$ granulated yeast extract, $4 \mathrm{~mL}$ glycerol $87 \%, 900 \mathrm{~mL}$ of distilled $\left.\mathrm{H}_{2} \mathrm{O}\right)$ supplemented with ampicillin $(100 \mu \mathrm{g} / \mathrm{mL})$. After $24 \mathrm{hrs}$ of incubation the whole volume of the bacterial culture was inoculated in $1000 \mathrm{~mL}$ of fresh broth. When the density of the culture had reached the $\mathrm{OD}_{600 \mathrm{~nm}}$ value of 0.8 , the Ang expression was induced by the addition of $1 \mathrm{mM}$ IPTG and the incubation was continued for additional $2 \mathrm{~h}$. Afterwards, the cell culture was harvested by centrifugation (15 min at $1503 \mathrm{RCF}$ ) and cells were lysed with $30 \mathrm{~mL}$ of lysis buffer ( $50 \mathrm{mM}$ Tris-HCl, $2 \mathrm{mM}$ EDTA, $\mathrm{pH}=8$ ) by using a high-pressure homogenizer (Emulsiflex, Ottawa, Canada) and a sonication step (Sonicator Q700, Qsonica, Newtown, CT, USA). Lysate was centrifuged ( $40 \mathrm{~min}$ at 15,871 RCF) and the pellet was re-suspended in $25 \mathrm{~mL}$ of lysis buffer supplemented with $1 \%(v / v)$ Triton X-100. Sonication and centrifugation steps were repeated twice and the final pellet was dissolved in $30 \mathrm{~mL}$ of denaturation buffer $(0.24 \mathrm{M} \mathrm{GdnHCl}, 100 \mathrm{mM}$ Tris-HCl, $1 \mathrm{mM}$ EDTA, $4 \mathrm{mM} \mathrm{NaCl}, 0.4 \mathrm{mM}$ DTT).

The expressed recombinant angiogenin (rANG) was refolded from inclusion bodies according to the procedure described by Jang et al. [83] and then purified by a cation exchange chromatography performed on an automated chromatographic workstation (Akta prime, GE Healthcare, Milan, Italy) equipped with a $15 \times 1.6 \mathrm{~cm}$ column packed with SP Sepharose Fast Flow (GE Healthcare, Milan, Italy). After a washing step with $25 \mathrm{mM}$ Tris- $\mathrm{HCl}(\mathrm{pH}=8.0)$, rAng was eluted with $25 \mathrm{mM}$ Tris- $\mathrm{HCl}$, $1 \mathrm{M} \mathrm{NaCl}(\mathrm{pH}=8.0)$ buffer solution. Sodium dodecyl sulphate-polyacrylamide gel electrophoresis (SDS-PAGE) (10\% bis-tris, Invitrogen, Carlsbad, CA, USA, $1 \mathrm{~mm} \times 15$ well) was carried out to evaluate the presence of dimers.

To obtain wild-type angiogenin (ANG), rANG was incubated with $1 \mathrm{nM}$ Aeromonas aminopeptidase, at the concentration of $1 \times 10^{-5} \mathrm{M}$ in $200 \mathrm{mM}$ PBS ( $\mathrm{pH}=7.2$ ) (overnight at $37^{\circ} \mathrm{C}$ under gentle shaking). This procedure allows for the specific removal of the N-terminal methionine residue, Met(-1), in the primary sequence of rANG, thus obtaining the N-terminal glutamine residue, Glu1, that spontaneously cyclises to the pyroglutamate residue, PyrGlu1, which is characteristic of 'native' wtANG.

The reaction mixture was purified by dialysis (Spectra/por MWCO 6-8000) (Fisher Scientific, Hampton, NH, USA), which replaces PBS with $25 \mathrm{mM}$ Tris-HCl (pH 7.4) buffer solution, followed by cation-exchange chromatography. The native folding of wtANG was evaluated by testing the ribonucleolytic activity of the protein, according to the procedure reported by Halloway et al. [82]. The protein concentration was determined by means of UV-visible spectroscopy $\left(\varepsilon_{280 \mathrm{~nm}}=12,500 \mathrm{M}^{-1} \mathrm{~cm}^{-1}\right)$ [38].

\subsection{UV-Visible Spectroscopy, Circular Dichroism Spectroscopy and Dynamic Light Scattering (DLS) Analyses}

UV-visible spectra of the aqueous dispersions were measured on a Lambda $2 \mathrm{~S}$ spectrometer (Perkin Elmer, Waltham, MA, USA) using conventional quartz cells (light path $1 \mathrm{~cm}$ and $0.1 \mathrm{~cm}$ ) under the following conditions: bandwidth, $1 \mathrm{~nm}$; scan rate, $100 \mathrm{~nm} / \mathrm{min}$; response, medium; data interval, $0.5 \mathrm{~nm}$. Circular dichroism (CD) spectra in the $290-750 \mathrm{~nm}$ UV-visible region were recorded at $25^{\circ} \mathrm{C}$ in 
a constant nitrogen flow on a model 810 spectropolarimeter (Jasco, Cremella (LC), Italy) equipped with a Xe lamp. The following conditions were used: scan rate, $50 \mathrm{~nm} \mathrm{~min}{ }^{-1}$; bandwidth, $1 \mathrm{~nm}$; scan rate, $50 \mathrm{~nm} / \mathrm{min}$; response, $4 \mathrm{~s}$; accumulation, 3 times; data interval, $0.5 \mathrm{~nm}$. Aqueous solution of $(+)$-ammonium camphorsulfonate- $\mathrm{d}_{10}(0.06 \%)$ was used for a calibration of the spectrometer sensitivity and wavelength $(\theta=190.4 \mathrm{mdeg}$ at $\lambda=290.5 \mathrm{~nm})$.

For the hydrodynamic size determination, a dynamic light scattering (DLS) nanoparticle size analyser (LB-550, Horiba, Rome, Italy) was used. The instrument, equipped with temperature controller in the range of $5-70{ }^{\circ} \mathrm{C}$, could detect particle size in the range of $1 \mathrm{~nm}-6 \mu \mathrm{m}$; response time, about $30 \mathrm{~s}$. The results are presented as the mean of at least three measurements.

\subsection{Synthesis and Functionalisation of Gold Nanoparticles}

Gold nanoparticles were synthesized modifying the method pioneered by Turkevich. This method uses the chemical reduction of the chloroauric acid by the action of trisodium citrate that acts as both reducing and capping agent [84]. The synthesis was carried out as follows. All glassware was cleaned with aqua-regia rinsing $\left(\mathrm{HCl}: \mathrm{HNO}_{3}, 1: 3\right.$ volume ratio) and then washed with MilliQ water immediately before starting the experiments. Gold(III) chloride dihydrate was dissolved in $20 \mathrm{~mL}$ of ultrapure Millipore water. The solution, at the final concentration of $1 \mathrm{mM}$, was heated to boiling on a hot plate while it is stirred in a $50 \mathrm{~mL}$ beaker. $2 \mathrm{~mL}$ of a $1 \%(\mathrm{~m} / \mathrm{v})$ solution of trisodium citrate dihydrate was quickly added to the rapidly-stirred auric solution. As soon as the solution turned from yellow to deep red, AuNPs were formed and the beaker was removed from the hot plate.

The concentration of synthesized AuNPs was typically of $16 \mathrm{nM}$, as estimated by the UV-visible spectra, according to the molar extinction coefficient $\varepsilon\left(\mathrm{in}^{-1} \mathrm{~cm}^{-1}\right.$,) calculated by the following equation [85]: $\varepsilon_{\text {gold }}=A d \gamma$, where $d$ in (nm) is the core diameter of the nanoparticle, $A$ and $\gamma$ are constants ( $\left.\mathrm{d} \leq 85 \mathrm{~nm}: A=4.7 \times 10^{4}, \gamma=3.30 ; \mathrm{d}>85 \mathrm{~nm}: A=1.6 \times 10^{8}, \gamma=1.47\right)$.

To calculate $d$, the UV-visible parameters of the plasmon peak were used, according to the following equation [47]: $d=\frac{\lambda \max -515.04}{0.3647}$.

In order to remove the excess of sodium citrate, the citrate-capped gold nanoparticles were washed through two centrifugation steps (15 min at $6010 \mathrm{RCF}$ ), with rinsing in between and at the end with 3-(N-morpholino)propanesulfonic acid) -Tris(2-carboxyethyl)phosphine hydrochloride MOPS-TCEP buffer. To prepare the MOPS-TCEP buffer, $1 \mathrm{mM}$ MOPS buffer solution (added with $0.27 \mathrm{mM} \mathrm{KCl}$ and $13.7 \mathrm{mM} \mathrm{NaCl})$ was mixed to TCEP at 1:1 molar ratio, and the $\mathrm{pH}$ corrected to $7.4\left(25^{\circ} \mathrm{C}\right)$ by the addition of concentrated $\mathrm{NaOH}$.

The pellets of the rinsed citrate-capped gold nanoparticles were resuspended in $1 \mathrm{mM}$ MOPS-TCEP at the concentration of $1.5 \times 10^{-8} \mathrm{M}$, corresponding to $1.7 \times 10^{8} \mathrm{AuNP} / \mathrm{mL}$, as determined by the absorbance of the plasmon peak, and functionalized by physical adsorption (for Ang $60-68$ and ANG), and prevalent chemisorption (for Ang ${ }_{60-68} \mathrm{Cys}$ ). The functionalization was carried out through the gradual addition, in a concentration range from $5 \times 10^{-6} \mathrm{M}$ up to $3 \times 10^{-5} \mathrm{M}$, of the two different peptides (Ang ( $0-68$ and $\mathrm{Ang}_{60-68} \mathrm{Cys}$ ) and through the one step addition of the whole protein (ANG) at the concentration of $1 \times 10^{-7} \mathrm{M}$, to $1.5 \times 10^{-8} \mathrm{M}$ aqueous dispersion of AuNP and analysed by UV-visible spectroscopy titrations. Eventually, to rinse off unbounded or weakly bound biomolecules, the peptide-AuNP hybrid systems were purified by two centrifugation steps (15 min at 6010 RCF), with rinsing in between and at the end with MOPS-TCEP buffer.

\subsection{Cellular Experiments}

Human neuroblastoma cells (SH-SY5Y cell line) were cultivated in full medium, i.e., DMEM/F12 supplemented with $10 \%$ FBS, $2 \mathrm{mM}_{\mathrm{L}}$-glutamine and $100 \mu \mathrm{g} \mathrm{mL} \mathrm{m}^{-1}$ streptomycin. For differentiation, cells were seeded at a density of $2.3 \times 10^{5}$ cells $/ \mathrm{mL}$ in full medium for $24 \mathrm{hrs}$ and then neuronal differentiation of SH-SY5Y was induced by treatment for 5 days in vitro (DIV) with $10 \mu \mathrm{M}$ of retinoic acid (RA) for 5 days in Dulbecco's Modified Eagle Medium (DMEM) high glucose medium supplemented with $0.5 \%$ of FBS. 
Human glioblastoma cell line (A172) was cultivated in DMEM (n. 30-2002) supplemented with $10 \% \mathrm{FBS}$ and $100 \mu \mathrm{g} \cdot \mathrm{mL}^{-1}$ streptomycin. The cell cultures were grown in tissue-culture treated Corning ${ }^{\circledR}$ flasks (Sigma-Aldrich) in humidified atmosphere $\left(5 \% \mathrm{CO}_{2}\right)$ at $37^{\circ} \mathrm{C}$ (HeraCell $150 \mathrm{C}$ incubator, Heraeus, Hanau, Germany). For the cellular treatments, the day before the experiment glioblastoma cells were seeded at a density of $2 \times 10^{5}$ cells $/ \mathrm{mL}$ in full medium.

\subsubsection{Cellular Experiments}

Corning ${ }^{\circledR} 48$ well multiwell plates were used for cytotoxicity assays (Sigma-Aldrich). The effect of AuNPs with ANG protein and Ang peptides on cell viability was tested at $50-60 \%$ of cell confluence by incubation with the compounds with concentrations 5 and $10 \mathrm{nM}$ with or without $20 \mathrm{uM}$ of copper for $24 \mathrm{hrs}$ in DMEM medium supplemented with $0.5 \%$ of FBS. The viable cells were quantified by the reaction with MTT. After $90 \mathrm{~min}$, the reaction was stopped by adding DMSO, and absorbance was measured at $570 \mathrm{~nm}$ (Varioskan ${ }^{\circledR}$ Flash Spectral Scanning Multimode Readers, Thermo Scientific, Waltham, MA, USA). Results were expressed as \% of viable cells over the concentration of each compound. The experiments were repeated at least five times in triplicate and results expressed as mean \pm standard error of the mean (SEM). The statistical analysis was performed with a one-way Analysis of Variance (ANOVA test, by using the Origin software, version 8.6, Microcal, Northampton, MA, USA.

\subsubsection{Western Blot (WB) Analysis}

For the determination of protein amount by $\mathrm{WB}$, cells were cultivated at $37{ }^{\circ} \mathrm{C}$ (in $5 \% \mathrm{CO}_{2}$ atmosphere) on Corning ${ }^{\circledR}$ tissue-culture treated culture dishes $60 \mathrm{~mm} \times 15 \mathrm{~mm}(\mathrm{D} \times \mathrm{H})($ Sigma-Aldrich) at $80 \%$ of confluence. Cells lysates were prepared by cells treatment with RIPA lysis buffer $(50 \mathrm{mM}$ Tris-HCl, pH 8.0, $150 \mathrm{mM} \mathrm{NaCl}, 0.5$ mM EDTA, 1\% Triton X-100, 0.5 mM EGTA, 1\% NP40) containing an inhibitor of the protease and phosphatase cocktail. Immediately after the addition of the buffer, cells were collected by the scratch method and transferred to Eppendorf tubes $(1.5 \mathrm{~mL}$ of size, purchased from Sigma-Aldrich) for incubation on ice for $30 \mathrm{~min}$. After a centrifugation step (10 min at 18,407 RCF) the supernatants were collected and the protein concentration was measured by Bradford's method using BSA as the standard curve. SDS-PAGE with precast gel (4-20\%, mini-PROTEAN, BioRad, Hercules, CA, USA) was used to separate proteins lysates or Ang protein and peptides. Nitrocellulose membranes (Sigma-Aldrich) were used to transfer proteins from the gel. Membranes were incubated with blocking buffer $(0.1 \%$ Tween 20 in tris-buffered saline added with either $5 \%$ non-fat milk) at room temperature for $1 \mathrm{~h}$, and then incubated with primary anti-angiogenin or anti-GAPDH antibody (code: sc-9044, 1:500 dilution, Santa Cruz Biotechnology (Dallas, TX, USA) or code: ab8245, 1:2000 dilution, Abcam (Cambridge, UK), respectively) overnight at $4{ }^{\circ} \mathrm{C}$. After that, $1 \mathrm{~h}$ treatment with goat anti-rabbit or anti-mouse IgG horseradish peroxidase-conjugated secondary antibodies (code: AP307P and AP181P, respectively, 1:3000 dilution, MD Millipore Bioscience (Burlington, MA, USA). Measurements were performed by a ChemiDoc MP Imaging System (BioRad, Hercules, CA, USA) using enhanced Western Lighting Chemiluminescence Reagent Plus (PerkinElmer, Waltham, MA, USA).

\subsubsection{Dot Blot Analysis}

Peptides or whole protein were dissolved in phosphate buffer saline solution (PBS, $\mathrm{pH}=7.4$ ) at $0.2 \mathrm{mg} / \mathrm{mL}$. Using narrow-mouth pipette tip, $2 \mu \mathrm{L}$ of samples were spotted onto the nitrocellulose membrane. To block the non-specific sites membrane was incubated in $5 \%$ non-fat milk in $0.1 \%$ Tween 20 in tris-buffered (30 min, room temperature). After that, membranes were incubated with primary anti-angiogenin antibody (code: sc-9044, 1:500 dilution, from Santa Cruz Biotechnology, Dallas, TX, USA) overnight at $4{ }^{\circ} \mathrm{C}$. Than membranes were incubated with secondary antibody conjugated with horseradish peroxidase (HRP) enzyme (code: AP307P, 1:3000 dilution, MD Millipore Bioscience, Burlington, MA, USA) for $1 \mathrm{~h}$. Measurements were performed by a ChemiDoc MP Imaging System 
(BioRad, Hercules, CA, USA) using enhanced Western Lighting Chemiluminescence Reagent Plus (PerkinElmer, Waltham, MA, USA).

\subsubsection{Quantitative qPCR}

For qPCR experiments, cells were cultivated at $37^{\circ} \mathrm{C}$ (in $5 \% \mathrm{CO}_{2}$ atmosphere) on Corning ${ }^{\circledR}$ tissue-culture treated culture dishes $60 \mathrm{~mm} \times 15 \mathrm{~mm}(\mathrm{D} \times \mathrm{H})$ (Sigma-Aldrich) at $80 \%$ of confluence. Total RNA was extracted with TRIzol (Life Technologies, Foster City, CA, USA), according to the manufacturer's instructions. RNA quantification was performed by Epoch $^{\mathrm{TM}}$ Microplate Spectrophotometer $\left(\right.$ BioTek $^{\circledR}$, Winooski, VT, USA). Extracted RNA was reverse transcribed by using a High Capacity RNA-to-cDNA Kit (Life Technologies), according to the manufacturer's instructions. Resulting cDNAs (30 ng per sample) were amplified through a LightCycler ${ }^{\circledR} 480$ System (Roche, Pleasanton, CA, USA). Single-gene specific assays were performed through real-time PCR by using Fast SYBR Green Master Mix (Life Technologies, Carlsbad, CA, USA) according to the manufacturer's instruction. To allow statistical analysis, PCRs were performed in three independent biological replicates. $18 \mathrm{~S}$ was used as housekeeping gene to normalize PCR data. Primer sequences are listed in Table 3.

Table 3. Primer sequences for vascular endothelial growth factor A (VEGFA) and 18S ribosomal RNA (18S) genes.

\begin{tabular}{|c|c|c|}
\hline Gene Symbol & Forward & Reverse \\
\hline $\begin{array}{c}\text { Human VEGFA } \\
18 \mathrm{~S}\end{array}$ & $\begin{array}{l}\text { 5'-ATCTTCAAGCCATCCTGTGTGC-3' } \\
\text { 5'-AGTCCCTGCCCTTTGTACACA-3' }\end{array}$ & 5'- GAGGTTTGATCCGCATAATCTG-3' \\
\hline
\end{tabular}

\subsubsection{Sandwich ELISA Assay}

Medium samples were collected after a 24-h treatment exposure with AuNPs, ANG and peptides, and hybrids Ang $60-68 \_N P$, Ang $_{60-68}$ Cys_NP and ANG_NP in DMEM medium supplemented with 0.5\% of FBS and centrifuged $(14,000 \times g, 10 \mathrm{~min})$, the supernatants were transferred into clean microtubes and stored at $-80{ }^{\circ} \mathrm{C}$ until analysed. The concentration of VEGF release was determined from the cell culture media samples using ELISA sandwich assay. Polyvinyl chloride (PVC) microtiter plates were coated overnight at $4{ }^{\circ} \mathrm{C}$ with $5 \mu \mathrm{g} / \mathrm{mL}$ of capture antibody (anti-VEGF, code: PAB12284) in carbonate/bicarbonate buffer ( $\mathrm{pH}$ 9.6). Then plates were washed twice with PBS, blocked by blocking buffer ( $5 \%$ non-fat dry milk/PBS) for 2 hrs at room temperature, washed with PBS and incubated with cell culture media samples for $90 \mathrm{~min}$ at $37^{\circ} \mathrm{C}$. After plates were washed with PBS, incubated for $2 \mathrm{hrs}$ with $1 \mu \mathrm{g} / \mathrm{mL}$ of detection antibody (anti-VEGF, code: H00007422-M05), washed again, then incubated for $2 \mathrm{hrs}$ with HRP-conjugated secondary antibody and washed with PBS. Result was detected by $3,3^{\prime}, 5,5^{\prime}$-tetramethylbenzidine (TMB) solution after the incubation for $15 \mathrm{~min}$. The reaction was stopped by stopping solution $\left(2 \mathrm{M} \mathrm{H}_{2} \mathrm{SO}_{4}\right)$ and the optical density was measured at $450 \mathrm{~nm}$ by a plate reader (Varioskan ${ }^{\circledR}$ Flash Spectral Scanning Multimode Reader, Waltham, MA, USA).

\subsubsection{Laser Scanning Confocal Microscopy (LSM)}

SH-SY5Y cells were seeded $\left(30 \times 10^{3}\right.$ cells per dish) and differentiated (see 2.6.1) in glass bottom dishes with $22 \mathrm{~mm}$ of glass diameter (WillCo-dish ${ }^{\circledR}$, Willco Wells, B.V., Amsterdam Netherlands). Glioblastoma cells were seeded at the density $30 \times 10^{3}$ cells per dish in glass bottom dishes with complete medium for $24 \mathrm{hrs}$ until cellular adhesion with a minimal cell confluence of $50 \%$ was attained. Thereafter, cells were treated with AuNPs $(5 \mathrm{nM})$ or ANG $(100 \mathrm{nM})$ or angiogenin peptides $(30 \mu \mathrm{M})$ and their hybrids in the presence or absence of copper for $2 \mathrm{hrs}$ in DMEM high glucose medium without FBS. After the incubation time, cells were stained with nuclear dye Hoechst33342, washed with PBS, and fixed with high purity $2 \%$ paraformaldehyde in PBS $(\mathrm{pH}=7.3)$. Afterwards, cells were permeabilized with $0.5 \%$ Triton X-100 with $0.1 \%$ BSA and stained firstly with a high-affinity 
F-actin probe (Actin Green 488 Ready Probes Reagent, ThermoFisher), conjugated to green-fluorescent Alexa Fluor ${ }^{\circledR} 488$ dye for $30 \mathrm{~min}$, washed with PBS and then with anti-angiogenin antibody (code: sc-9044, 1:50 dilution, Santa Cruz Biotechnology, Dallas, TX, USA) overnight at $4{ }^{\circ} \mathrm{C}$. After that, $1 \mathrm{~h}$ treatment with donkey anti-rabbit IgG H\&L (Alexa Fluor ${ }^{\circledR} 568$ ) pre-adsorbed secondary antibodies (code: ab175692, 1:1000 dilution, MD Millipore Bioscience, Burlington, MA, USA).

For multichannel imaging, fluorescent dyes were imaged sequentially to eliminate cross talk between the channels, namely: (i) the blue (ex405/em 425-475), for the emission of the Hoechst33342-stained nuclei, (ii) the green (ex488/em 500-530), for the emission of the Actin Green 488 Ready Probes Reagent, (iii) the red (ex543/em 560-700), for Alexa Fluor ${ }^{\circledR} 568$ of secondary antibody.

Confocal imaging microscopy was performed with a FV1000 confocal laser scanning microscope (LSM, Olympus, Tokyo, Japan), equipped with diode UV (405 nm, $50 \mathrm{~mW})$, multiline Argon (457 nm, $488 \mathrm{~nm}, 515 \mathrm{~nm}$, total $30 \mathrm{~mW}), \mathrm{HeNe}(\mathrm{G})(543 \mathrm{~nm}, 1 \mathrm{~mW})$ and $\mathrm{HeNe}(\mathrm{R})(633 \mathrm{~nm}, 1 \mathrm{~mW})$ lasers. An oil immersion objective (60xO PLAPO) and spectral filtering system were used. The detector gain was fixed at a constant value and images were taken, in sequential mode, for all the samples at random locations throughout the area of the well. The image analysis was carried out using Huygens Essential software (by Scientific Volume Imaging B.V., Hilversum, The Netherlands).

\section{Conclusions}

The results obtained from experiment performed on A172 cells indicate that $\mathrm{Ang}_{60-68}$ Cys and Ang $60-68$ anchored on AuNPs could be considered as effective inhibitors of glioblastoma tumour cell proliferation and VEGF release. However, the mechanism of action and potential side effects need to be elucidated further. Moreover, exogenous delivery of angiogenin by gold nanoparticles could represent a strategic approach to re-establish the physiological concentrations of angiogenin in the course of diseases in which the protein levels are strongly reduced and suggests that further studies are required to translate these effects into meaningful therapies.

Our results demonstrated that copper induced a decrease of VEGF mRNA transcription on d-SH-SY5Y cells. These data confirmed those of other studies, demonstrating the toxic effect of the copper on SH-SY5Y cells, particularly on the mitochondria, with decreased levels of mitochondrial proteins [86]. On the other hand, the treatment of A172 cancer cells with $\mathrm{Cu}(\mathrm{II})$ induced an increase of VEGF release, demonstrating the different role of the copper in both tumoral and non-tumoral cells. It has been demonstrated that copper induces the expression of VEGF in breast and hepatic cancer cells through the activation of the epidermal growth factor receptor/extracellular signal-regulated protein kinases (EGFR/ERK)/c-fos transduction pathway [87]. Surprisingly, the incubation of A172 cells with copper in presence of $\mathrm{Ang}_{60-68} \mathrm{Cys} \_\mathrm{NP}$ potentiated the inhibitory effect of the protein fragment on VEGF release, demonstrating the therapeutic potential of copper chelating agents against tumour progression. However, the mechanism of action and potential side effects need to be elucidated further.

Supplementary Materials: The following are available online at http://www.mdpi.com/2072-6694/11/9/1322/s1, Figure S1: Densitometric analyses (a) and representative Western blot (b) of SH-SY5Y, differentiated SH-SY5Y and A172 cell lysates.

Author Contributions: Conceptualization, D.L.M. and C.S.; methodology, G.L. and C.S.; validation and formal analysis, C.D.A. and D.L.M.; investigation, I.N., L.M.C., F.D. and A.M.; data curation, L.M.C. and F.D.; writing-original draft preparation, I.N., L.M.C. and F.D.; writing—review and editing, D.L.M., G.L. and C.S.

Funding: This research was partially funded by MIUR under Grant PRIN 2015 (20152EKS4Y project) and University of Catania (Piano della Ricerca di Ateneo, Linea di Intervento 2, 2018-2020). D.L.M. acknowledges University of Pisa (PRA_2017_51).

Acknowledgments: Örjan Hansson (Gothenburg University, Sweden) is kindly acknowledged for the scientific and technical support in the expression of wild type angiogenin.

Conflicts of Interest: The authors declare no conflict of interest. The funders had no role in the design of the study; in the collection, analyses, or interpretation of data; in the writing of the manuscript, or in the decision to publish the results. 


\section{References}

1. Spicer, C.D.; Jumeaux, C.; Gupta, B.; Stevens, M.M. Peptide and protein nanoparticle conjugates: Versatile platforms for biomedical applications. Chem. Soc. Rev. 2018, 47, 3574-3620. [CrossRef]

2. Cucci, L.; Naletova, I.; Consiglio, G.; Satriano, C. A Hybrid Nanoplatform of Graphene Oxide/Nanogold for Plasmonic Sensing and Cellular Applications at the Nanobiointerface. Appl. Sci. 2019, 9, 676. [CrossRef]

3. Di Pietro, P.; Strano, G.; Zuccarello, L.; Satriano, C. Gold and Silver Nanoparticles for Applications in Theranostics. Curr. Top. Med. Chem. 2016, 16, 3069-3102. [CrossRef]

4. Xu, R.; Xu, Y. Modern Inorganic Synthetic Chemistry, 2nd ed.; Elsevier: Amsterdam, The Netherlands, 2017; p. xxii, 785 Seiten.

5. Singh, P.; Pandit, S.; Mokkapati, V.; Garg, A.; Ravikumar, V.; Mijakovic, I. Gold Nanoparticles in Diagnostics and Therapeutics for Human Cancer. Int. J. Mol. Sci. 2018, 19, 1979. [CrossRef] [PubMed]

6. Satriano, C.; Munzone, A.; Cucci, L.M.; Giacomelli, C.; Trincavelli, M.L.; Martini, C.; Rizzarelli, E.; La Mendola, D. Angiogenin-mimetic peptide functionalised gold nanoparticles for cancer therapy applications. Microchem. J. 2018, 136, 157-163. [CrossRef]

7. Qing, Y.; Cheng, L.; Li, R.; Liu, G.; Zhang, Y.; Tang, X.; Wang, J.; Liu, H.; Qin, Y. Potential antibacterial mechanism of silver nanoparticles and the optimization of orthopedic implants by advanced modification technologies. Int. J. Nanomed. 2018, 13, 3311-3327. [CrossRef]

8. Di Pietro, P.; Zaccaro, L.; Comegna, D.; Del Gatto, A.; Saviano, M.; Snyders, R.; Cossement, D.; Satriano, C.; Rizzarelli, E. Silver nanoparticles functionalized with a fluorescent cyclic RGD peptide: A versatile integrin targeting platform for cells and bacteria. RSC Adv. 2016, 6, 112381-112392. [CrossRef]

9. DeFrates, K.; Markiewicz, T.; Gallo, P.; Rack, A.; Weyhmiller, A.; Jarmusik, B.; Hu, X. Protein Polymer-Based Nanoparticles: Fabrication and Medical Applications. Int. J. Mol. Sci. 2018, 19, 1717. [CrossRef]

10. Muñoz-Juan, A.; Carreño, A.; Mendoza, R.; Corchero, J.L. Latest Advances in the Development of Eukaryotic Vaults as Targeted Drug Delivery Systems. Pharmaceutics 2019, 11, 300. [CrossRef]

11. Satriano, C.; Lupo, G.; Motta, C.; Anfuso, C.D.; Di Pietro, P.; Kasemo, B. Ferritin-supported lipid bilayers for triggering the endothelial cell response. Colloids Surf. B Biointerfaces 2017, 149, 48-55. [CrossRef]

12. Watkins, R.; Wu, L.; Zhang, C.; Davis, R.; Xu, B. Natural product-based nanomedicine: Recent advances and issues. Int. J. Nanomed. 2015, 10, 6055-6074. [CrossRef]

13. Chan, K.H.; Lee, W.H.; Zhuo, S.; Ni, M. Harnessing supramolecular peptide nanotechnology in biomedical applications. Int. J. Nanomed. 2017, 12, 1171-1182. [CrossRef]

14. Chen, G.; Xie, Y.; Peltier, R.; Lei, H.; Wang, P.; Chen, J.; Hu, Y.; Wang, F.; Yao, X.; Sun, H. Peptide-Decorated Gold Nanoparticles as Functional Nano-Capping Agent of Mesoporous Silica Container for Targeting Drug Delivery. ACS Appl. Mater. Interfaces 2016, 8, 11204-11209. [CrossRef]

15. Silva, S.; Almeida, A.J.; Vale, N. Combination of Cell-Penetrating Peptides with Nanoparticles for Therapeutic Application: A Review. Biomolecules 2019, 9, 22. [CrossRef]

16. Sheng, J.; Xu, Z. Three decades of research on angiogenin: A review and perspective. Acta Biochim. Biophys. Sin. (Shanghai) 2016, 48, 399-410. [CrossRef]

17. Tsuji, T.; Sun, Y.; Kishimoto, K.; Olson, K.A.; Liu, S.; Hirukawa, S.; Hu, G.-f. Angiogenin Is Translocated to the Nucleus of HeLa Cells and Is Involved in Ribosomal RNA Transcription and Cell Proliferation. Cancer Res. 2005, 65, 1352-1360. [CrossRef]

18. Kieran, D.; Sebastia, J.; Greenway, M.J.; King, M.A.; Connaughton, D.; Concannon, C.G.; Fenner, B.; Hardiman, O.; Prehn, J.H. Control of motoneuron survival by angiogenin. J. Neurosci. 2008, 28, 14056-14061. [CrossRef]

19. Koutroubakis, I.E.; Xidakis, C.; Karmiris, K.; Sfiridaki, A.; Kandidaki, E.; Kouroumalis, E.A. Serum Angiogenin in Inflammatory Bowel Disease. Dig. Dis. Sci. 2004, 49, 1758-1762. [CrossRef]

20. Tello-Montoliu, A.; Patel, J.V.; Lip, G.Y. Angiogenin: A review of the pathophysiology and potential clinical applications. J. Thromb. Haemost. 2006, 4, 1864-1874. [CrossRef]

21. Strydom, D.J.; Fett, J.W.; Lobb, R.R.; Alderman, E.M.; Bethune, J.L.; Riordan, J.F.; Vallee, B.L. Amino acid sequence of human tumor derived angiogenin. Biochemistry 1985, 24, 5486-5494. [CrossRef]

22. Eberle, K.; Oberpichler, A.; Trantakis, C.; Krupp, W.; Knupfer, M.; Tschesche, H.; Seifert, V. The expression of angiogenin in tissue samples of different brain tumours and cultured glioma cells. Anticancer Res. 2000, 20, 1679-1684. 
23. Huang, L.; Huang, Y.; Guo, H. Dominant expression of angiogenin in NeuN positive cells in the focal ischemic rat brain. J. Neurol. Sci. 2009, 285, 220-223. [CrossRef]

24. Maki, T.; Morancho, A.; Martinez-San Segundo, P.; Hayakawa, K.; Takase, H.; Liang, A.C.; Gabriel-Salazar, M.; Medina-Gutiérrez, E.; Washida, K.; Montaner, J.; et al. Endothelial Progenitor Cell Secretome and Oligovascular Repair in a Mouse Model of Prolonged Cerebral Hypoperfusion. Stroke 2018, 49, 1003-1010. [CrossRef]

25. Gabriel-Salazar, M.; Morancho, A.; Rodriguez, S.; Buxo, X.; Garcia-Rodriguez, N.; Colell, G.; Fernandez, A.; Giralt, D.; Bustamante, A.; Montaner, J.; et al. Importance of Angiogenin and Endothelial Progenitor Cells After Rehabilitation Both in Ischemic Stroke Patients and in a Mouse Model of Cerebral Ischemia. Front. Neurol. 2018, 9, 508. [CrossRef]

26. Sebastia, J.; Kieran, D.; Breen, B.; King, M.A.; Netteland, D.F.; Joyce, D.; Fitzpatrick, S.F.; Taylor, C.T.; Prehn, J.H. Angiogenin protects motoneurons against hypoxic injury. Cell Death Differ. 2009, 16, 1238-1247. [CrossRef]

27. Steidinger, T.U.; Slone, S.R.; Ding, H.; Standaert, D.G.; Yacoubian, T.A. Angiogenin in Parkinson disease models: Role of Akt phosphorylation and evaluation of AAV-mediated angiogenin expression in MPTP treated mice. PLoS ONE 2013, 8, e56092. [CrossRef]

28. Moroianu, J.; Riordan, J.F. Nuclear translocation of angiogenin in proliferating endothelial cells is essential to its angiogenic activity. Proc. Natl. Acad. Sci. USA 1994, 91, 1677-1681. [CrossRef]

29. Kishimoto, K.; Liu, S.; Tsuji, T.; Olson, K.A.; Hu, G.-f. Endogenous angiogenin in endothelial cells is a general requirement for cell proliferation and angiogenesis. Oncogene 2004, 24, 445-456. [CrossRef]

30. Rosenstein, J.M.; Krum, J.M.; Ruhrberg, C. VEGF in the nervous system. Organogenesis 2010, 6, 107-114. [CrossRef]

31. Bush, A.I. The metal theory of Alzheimer's disease. J. Alzheimers Dis. 2013, 33 (Suppl. S1), S277-S281. [CrossRef]

32. Opazo, C.M.; Greenough, M.A.; Bush, A.I. Copper: From neurotransmission to neuroproteostasis. Front. Aging Neurosci. 2014, 6, 143. [CrossRef]

33. Urso, E.; Maffia, M. Behind the Link between Copper and Angiogenesis: Established Mechanisms and an Overview on the Role of Vascular Copper Transport Systems. J. Vasc. Res. 2015, 52, 172-196. [CrossRef]

34. Denoyer, D.; Masaldan, S.; La Fontaine, S.; Cater, M.A. Targeting copper in cancer therapy: 'Copper That Cancer'. Metallomics 2015, 7, 1459-1476. [CrossRef]

35. Giacomelli, C.; Trincavelli, M.L.; Satriano, C.; Hansson, O.; La Mendola, D.; Rizzarelli, E.; Martini, C. diamondCopper (II) ions modulate Angiogenin activity in human endothelial cells. Int. J. Biochem. Cell Biol. 2015, 60, 185-196. [CrossRef]

36. Badet, J.; Soncin, F.; Guitton, J.D.; Lamare, O.; Cartwright, T.; Barritault, D. Specific binding of angiogenin to calf pulmonary artery endothelial cells. Proc. Natl. Acad. Sci. USA 1989, 86, 8427-8431. [CrossRef]

37. Soncin, F.; Guitton, J.D.; Cartwright, T.; Badet, J. Interaction of human angiogenin with copper modulates angiogenin binding to endothelial cells. Biochem. Biophys. Res. Commun. 1997, 236, 604-610. [CrossRef]

38. La Mendola, D.; Arnesano, F.; Hansson, O.; Giacomelli, C.; Calo, V.; Mangini, V.; Magri, A.; Bellia, F.; Trincavelli, M.L.; Martini, C.; et al. Copper binding to naturally occurring, lactam form of angiogenin differs from that to recombinant protein, affecting their activity. Metallomics 2016, 8, 118-124. [CrossRef]

39. Gross, A.; Hashimoto, C.; Sticht, H.; Eichler, J. Synthetic Peptides as Protein Mimics. Front. Bioeng. Biotechnol. 2015, 3, 211. [CrossRef]

40. Trapani, G.; Satriano, C.; La Mendola, D. Peptides and their Metal Complexes in Neurodegenerative Diseases: From Structural Studies to Nanomedicine Prospects. Curr. Med. Chem. 2018, 25, 715-747. [CrossRef]

41. Strydom, D.J. The angiogenins. Cell. Mol. Life Sci. 1998, 54, 811-824. [CrossRef]

42. Gao, X.; Xu, Z. Mechanisms of action of angiogenin. Acta Biochim. Biophys. Sin. (Shanghai) 2008, 40, 619-624. [CrossRef]

43. Magri, A.; Munzone, A.; Peana, M.; Medici, S.; Zoroddu, M.A.; Hansson, O.; Satriano, C.; Rizzarelli, E.; La Mendola, D. Coordination Environment of $\mathrm{Cu}(\mathrm{II})$ Ions Bound to N-Terminal Peptide Fragments of Angiogenin Protein. Int. J. Mol. Sci. 2016, 17, 1240. [CrossRef]

44. Cucci, L.M.; Munzone, A.; Naletova, I.; Magri, A.; La Mendola, D.; Satriano, C. Gold nanoparticles functionalized with angiogenin-mimicking peptides modulate cell membrane interactions. Biointerphases 2018, 13, 03C401. [CrossRef] [PubMed] 
45. Plate, K.H. Mechanisms of angiogenesis in the brain. J. Neuropathol. Exp. Neurol. 1999, 58, 313-320. [CrossRef] [PubMed]

46. Lupo, G.; Caporarello, N.; Olivieri, M.; Cristaldi, M.; Motta, C.; Bramanti, V.; Avola, R.; Salmeri, M.; Nicoletti, F.; Anfuso, C.D. Anti-angiogenic Therapy in Cancer: Downsides and New Pivots for Precision Medicine. Front. Pharmacol. 2016, 7, 519. [CrossRef]

47. He, Y.Q.; Liu, S.P.; Kong, L.; Liu, Z.F. A study on the sizes and concentrations of gold nanoparticles by spectra of absorption, resonance Rayleigh scattering and resonance non-linear scattering. Spectrochim. Acta A Mol. Biomol. Spectrosc. 2005, 61, 2861-2866. [CrossRef] [PubMed]

48. La Mendola, D.; Magri, A.; Vagliasindi, L.I.; Hansson, O.; Bonomo, R.P.; Rizzarelli, E. Copper(II) complex formation with a linear peptide encompassing the putative cell binding site of angiogenin. Dalton Trans. 2010, 39, 10678-10684. [CrossRef]

49. Yamazaki, D.; Kurisu, S.; Takenawa, T. Regulation of cancer cell motility through actin reorganization. Cancer Sci. 2005, 96, 379-386. [CrossRef] [PubMed]

50. Hohmann, T.; Dehghani, F. The Cytoskeleton-A Complex Interacting Meshwork. Cells 2019, 8, 362. [CrossRef]

51. Xu, X.; Harder, J.; Flynn, D.C.; Lanier, L.M. AFAP120 regulates actin organization during neuronal differentiation. Differentiation 2009, 77, 38-47. [CrossRef]

52. Thiyagarajan, N.; Ferguson, R.; Subramanian, V.; Acharya, K.R. Structural and molecular insights into the mechanism of action of human angiogenin-ALS variants in neurons. Nat. Commun. 2012, 3, 1121. [CrossRef]

53. Takano, S.; Yoshii, Y.; Kondo, S.; Suzuki, H.; Maruno, T.; Shirai, S.; Nose, T. Concentration of vascular endothelial growth factor in the serum and tumor tissue of brain tumor patients. Cancer Res. 1996, 56, 2185-2190.

54. Schiera, G.; Proia, P.; Alberti, C.; Mineo, M.; Savettieri, G.; Di Liegro, I. Neurons produce FGF2 and VEGF and secrete them at least in part by shedding extracellular vesicles. J. Cell. Mol. Med. 2007, 11, 1384-1394. [CrossRef]

55. Finney, L.; Vogt, S.; Fukai, T.; Glesne, D. Copper and angiogenesis: Unravelling a relationship key to cancer progression. Clin. Exp. Pharmacol. Physiol. 2009, 36, 88-94. [CrossRef]

56. Hu, G.F.; Riordan, J.F.; Vallee, B.L. A putative angiogenin receptor in angiogenin-responsive human endothelial cells. Proc. Natl. Acad. Sci. USA 1997, 94, 2204-2209. [CrossRef]

57. Vericat, C.; Vela, M.E.; Corthey, G.; Pensa, E.; Cortés, E.; Fonticelli, M.H.; Ibañez, F.; Benitez, G.E.; Carro, P.; Salvarezza, R.C. Self-assembled monolayers of thiolates on metals: A review article on sulfur-metal chemistry and surface structures. RSC Adv. 2014, 4, 27730-27754. [CrossRef]

58. Miller, M.M.; Lazarides, A.A. Sensitivity of Metal Nanoparticle Surface Plasmon Resonance to the Dielectric Environment. J. Phys. Chem. B 2005, 109, 21556-21565. [CrossRef]

59. Zhou, C.; Friedt, J.-M.; Angelova, A.; Choi, K.-H.; Laureyn, W.; Frederix, F.; Francis, L.A.; Campitelli, A.; Engelborghs, Y.; Borghs, G. Human Immunoglobulin Adsorption Investigated by Means of Quartz Crystal Microbalance Dissipation, Atomic Force Microscopy, Surface Acoustic Wave, and Surface Plasmon Resonance Techniques. Langmuir 2004, 20, 5870-5878. [CrossRef]

60. Díaz-Herrera, N.; González-Cano, A.; Viegas, D.; Santos, J.L.; Navarrete, M.-C. Refractive index sensing of aqueous media based on plasmonic resonance in tapered optical fibres operating in the $1.5 \mu \mathrm{m}$ region. Sens. Actuators B Chem. 2010, 146, 195-198. [CrossRef]

61. Acharya, K.R.; Shapiro, R.; Allen, S.C.; Riordan, J.F.; Vallee, B.L. Crystal structure of human angiogenin reveals the structural basis for its functional divergence from ribonuclease. Proc. Natl. Acad. Sci. USA 1994, 91, 2915-2919. [CrossRef]

62. Khlebtsov, B.N.; Khlebtsov, N.G. On the measurement of gold nanoparticle sizes by the dynamic light scattering method. Colloid J. 2011, 73, 118-127. [CrossRef]

63. Capanni, C.; Messori, L.; Orioli, P.; Chiti, F.; Stefani, M.; Ramponi, G.; Taddei, N.; Gabrielli, S. Investigation of the effects of copper ions on protein aggregation using a model system. Cell. Mol. Life Sci. (CMLS) 2004, 61, 982-991. [CrossRef]

64. Prenesti, E.; Daniele, P.G.; Toso, S. Visible spectrophotometric determination of metal ions: The influence of structure on molar absorptivity value of copper(II) complexes in aqueous solution. Anal. Chim. Acta 2002, 459, 323-336. [CrossRef] 
65. La Mendola, D.; Magri, A.; Santoro, A.M.; Nicoletti, V.G.; Rizzarelli, E. Copper(II) interaction with peptide fragments of histidine-proline-rich glycoprotein: Speciation, stability and binding details. J. Inorg. Biochem. 2012, 111, 59-69. [CrossRef]

66. Stanyon, H.F.; Cong, X.; Chen, Y.; Shahidullah, N.; Rossetti, G.; Dreyer, J.; Papamokos, G.; Carloni, P.; Viles, J.H. Developing predictive rules for coordination geometry from visible circular dichroism of copper(II) and nickel(II) ions in histidine and amide main-chain complexes. FEBS J. 2014, 281, 3945-3954. [CrossRef]

67. Hu, G.F. Neomycin inhibits angiogenin-induced angiogenesis. Proc. Natl. Acad. Sci. USA 1998, 95, 9791-9795. [CrossRef]

68. Liu, J.; Hu, R.; Liu, J.; Zhang, B.; Wang, Y.; Liu, X.; Law, W.-C.; Liu, L.; Ye, L.; Yong, K.-T. Cytotoxicity assessment of functionalized CdSe, CdTe and InP quantum dots in two human cancer cell models. Mater. Sci. Eng. C 2015, 57, 222-231. [CrossRef]

69. Kalinina, E.V.; Chernov, N.N.; Saprin, A.N. Involvement of thio-, peroxi-, and glutaredoxins in cellular redox-dependent processes. Biochemistry (Moscow) 2008, 73, 1493-1510. [CrossRef]

70. Salazar-Ramiro, A.; Ramírez-Ortega, D.; Pérez de la Cruz, V.; Hérnandez-Pedro, N.Y.; González-Esquivel, D.F.; Sotelo, J.; Pineda, B. Role of Redox Status in Development of Glioblastoma. Front. Immunol. 2016, 7. [CrossRef]

71. Lyons, S.M.; Fay, M.M.; Akiyama, Y.; Anderson, P.J.; Ivanov, P. RNA biology of angiogenin: Current state and perspectives. RNA Biol. 2017, 14, 171-178. [CrossRef]

72. Lee, F.S.; Shapiro, R.; Vallee, B.L. Tight-binding inhibition of angiogenin and ribonuclease A by placental ribonuclease inhibitor. Biochemistry 1989, 28, 225-230. [CrossRef]

73. Li, L.; Pan, X.Y.; Shu, J.; Jiang, R.; Zhou, Y.J.; Chen, J.X. Ribonuclease inhibitor up-regulation inhibits the growth and induces apoptosis in murine melanoma cells through repression of angiogenin and ILK/PI3K/AKT signaling pathway. Biochimie 2014, 103, 89-100. [CrossRef]

74. Dos Remedios, C.G.; Chhabra, D.; Kekic, M.; Dedova, I.V.; Tsubakihara, M.; Berry, D.A.; Nosworthy, N.J. Actin binding proteins: Regulation of cytoskeletal microfilaments. Physiol. Rev. 2003, 83, 433-473. [CrossRef] [PubMed]

75. Pyatibratov, M.G.; Kostyukova, A.S. New insights into the role of angiogenin in actin polymerization. Int. Rev. Cell Mol. Biol. 2012, 295, 175-198. [CrossRef]

76. Dutta, S.; Bandyopadhyay, C.; Bottero, V.; Veettil, M.V.; Wilson, L.; Pins, M.R.; Johnson, K.E.; Warshall, C.; Chandran, B. Angiogenin interacts with the plasminogen activation system at the cell surface of breast cancer cells to regulate plasmin formation and cell migration. Mol. Oncol. 2014, 8, 483-507. [CrossRef]

77. Yamasaki, S.; Ivanov, P.; Hu, G.F.; Anderson, P. Angiogenin cleaves tRNA and promotes stress-induced translational repression. J. Cell Biol. 2009, 185, 35-42. [CrossRef] [PubMed]

78. Saikia, M.; Jobava, R.; Parisien, M.; Putnam, A.; Krokowski, D.; Gao, X.H.; Guan, B.J.; Yuan, Y.; Jankowsky, E.; Feng, Z.; et al. Angiogenin-cleaved tRNA halves interact with cytochrome c, protecting cells from apoptosis during osmotic stress. Mol. Cell. Biol. 2014, 34, 2450-2463. [CrossRef]

79. Ruggero, D.; Pandolfi, P.P. Does the ribosome translate cancer? Nat. Rev. Cancer 2003, 3, 179-192. [CrossRef]

80. Xu, Z.-P.; Tsuji, T.; Riordan, J.F.; Hu, G.-F. The nuclear function of angiogenin in endothelial cells is related to rRNA production. Biochem. Biophys. Res. Commun. 2002, 294, 287-292. [CrossRef]

81. Wei, Y.; Wang, F.; Sang, B.; Xu, Z.; Yang, D. Activation of KRas-ERK1/2 signaling drives the initiation and progression of glioma by suppressing the acetylation of histone H4 at lysine 16. Life Sci. 2019, 225, 55-63. [CrossRef]

82. Holloway, D.E.; Hares, M.C.; Shapiro, R.; Subramanian, V.; Acharya, K.R. High-Level Expression of Three Members of the Murine Angiogenin Family in Escherichia coli and Purification of the Recombinant Proteins. Protein Expr. Purif. 2001, 22, 307-317. [CrossRef]

83. Jang, S.-H.; Kang, D.-K.; Chang, S.-I.; Scheraga, H.A.; Shin, H.-C. High level production of bovine angiogenin in E. coli by an efficient refolding procedure. Biotechnol. Lett. 2004, 26, 1501-1504. [CrossRef]

84. Turkevich, J.; Stevenson, P.C.; Hillier, J. A study of the nucleation and growth processes in the synthesis of colloidal gold. Discuss. Faraday Soc. 1951, 11. [CrossRef]

85. Navarro, J.R.G.; Werts, M.H.V. Resonant light scattering spectroscopy of gold, silver and gold-silver alloy nanoparticles and optical detection in microfluidic channels. Analyst 2013, 138, 583-592. [CrossRef] 
86. Arciello, M.; Rotilio, G.; Rossi, L. Copper-dependent toxicity in SH-SY5Y neuroblastoma cells involves mitochondrial damage. Biochem. Biophys. Res. Commun. 2005, 327, 454-459. [CrossRef]

87. Rigiracciolo, D.C.; Scarpelli, A.; Lappano, R.; Pisano, A.; Santolla, M.F.; De Marco, P.; Cirillo, F.; Cappello, A.R.; Dolce, V.; Belfiore, A.; et al. Copper activates HIF-1alpha/GPER/VEGF signalling in cancer cells. Oncotarget 2015, 6, 34158-34177. [CrossRef]

(C) 2019 by the authors. Licensee MDPI, Basel, Switzerland. This article is an open access article distributed under the terms and conditions of the Creative Commons Attribution (CC BY) license (http://creativecommons.org/licenses/by/4.0/). 